\title{
Mineral Constituents of Edible Field Parasol (Macrolepiota procera) Mushrooms and the Underlying Substrate from Upland Regions of Poland: Bioconcentration Potential, Intake Benefits, and Toxicological Risk
}

\author{
Anna K. Kojta ${ }^{1 *}$, Magdalena Gucia ${ }^{1}$, Grażyna Krasińska ${ }^{1}$, Martyna Saba ${ }^{1}$, \\ Innocent C. Nnorom ${ }^{2}$, Jerzy Falandysz ${ }^{1}$ \\ ${ }^{1}$ Gdańsk University, 63 Wita Stwosza Str., 80-308 Gdańsk, Poland \\ ${ }^{2}$ Abia State University, Uturu, Abia State, Nigeria
}

Received: 20 January 2016

Accepted: 5 May 2016

\begin{abstract}
This paper presents analytical and scientific monitoring data on the bioconcentration potential of trace elements and mineral compounds in Macrolepiota procera collected from background areas in upland regions of central Poland. The contents of $\mathrm{Ag}, \mathrm{Al}, \mathrm{Ba}, \mathrm{Ca}, \mathrm{Cd}, \mathrm{Co}, \mathrm{Cr}, \mathrm{Cu}, \mathrm{Fe}, \mathrm{K}, \mathrm{Mg}, \mathrm{Mn}, \mathrm{Na}, \mathrm{Pb}, \mathrm{Rb}, \mathrm{Sr}$, and $\mathrm{Zn}$ in caps and stipes (99 specimens) and underlying soil substrates were examined by ICP-OES and $\mathrm{Hg}$ by $\mathrm{CV}$-AAS after wet digestion. The results showed that $M$. procera is a rich source of especially $\mathrm{Ca}, \mathrm{Cu}, \mathrm{Fe}$, $\mathrm{K}, \mathrm{Mg}, \mathrm{Mn}, \mathrm{Na}$, and $\mathrm{Zn}$. The contents of $\mathrm{Pb}, \mathrm{Hg}, \mathrm{Ag}$, and $\mathrm{Cd}$ in the caps were $1.7 \pm 0.6$ to $5.9 \pm 1.7,1.8 \pm 0.8$ to $5.3 \pm 0.8,1.2 \pm 0.7$ to $16 \pm 7$, and $0.56 \pm 0.13$ to $4.9 \pm 5.4 \mathrm{mg} \mathrm{kg}^{-1}$ dry matter, respectively. Probable dietary intake assessment showed that occasional consumption (once a week) of Macrolepiota procera caps could be safe, while consumption more than once a week could provide doses of toxic metals that exceed the provisionally allowed daily intake limits for humans.
\end{abstract}

Keywords: foods, mushrooms, heavy metals, minerals, Macrolepiota procera

\section{Introduction}

Fungi play a key role in the transfer of metals from the lithosphere into the biosphere. Within the biodiverse world, mushrooms are the important groups that

*e-mail:anna.kojta@phdstud.ug.edu.pl constitute edible and medicinal mushrooms. Most of the estimated 2,000 species of edible wild mushrooms that grow worldwide are poorly characterized with respect to their composition and multi-mineral constituents as well as their bio-accessibility, while such information is completely absent for numerous species. In the studies of metallic elements and metalloids in mushrooms, the pertinent question is the unraveling of the qualitative and quantitative interrelationships between the elements/ 
compounds sequestered in the fruiting bodies from the soil or other substratum on which the mycelium develops [15].

Mushrooming is a global gourmet heritage practiced by both rural inhabitants and city dwellers. Nevertheless, sufficient knowledge of the composition and mineral constituents of many edible wild mushrooms available for picking is lacking [6-7]. Consequently, it has become common for only several of the well recognizable species to be collected and consumed. The few figures available on the annual intake rates of wild mushrooms shows that the average consumption varies by country: from $1.0 \mathrm{~kg}$ per capita in Sweden to $10 \mathrm{~kg}$ for fanciers in the Czech Republic, and as much as 20-24 kg per capita in the Liangshan Yi nationality in China. The portion of mushrooms in a single meal is usually $300 \mathrm{~g}$ (fresh weight), but this could sometimes be as much as $500 \mathrm{~g}$ [8]. Edible wild as well as cultivated mushrooms are highly popular among vegetarians and vegans.

In Poland, under a regulation issued by the Minister of Public Health and Welfare, 42 mushrooms can be purchased commercially, and these are readily available through retail sales. M. procera (common name field parasol or parasol mushroom) is on this ministerial list [9].

Edible wild mushrooms on sale in Poland are dominated by three groups or species, i.e.:

- Boletus spp., or the bay bolete (Imleria badia)

- Yellow-cracked bolete (Boletus subtomentosus) and golden bolete (Xerocomellus chrysenteron); Boletus spp., and in majority the king bolete (Boletus edulis)

- Common chanterelle (Cantharellus cibarius) [10]

Mushrooms, especially wild grown mushrooms and the edible species in particular, have been reported to be rich in mineral constituents as well as in some toxic metals [11-16]. As such, mushroom studies have shown that some mushroom species are rich sources of essential trace elements. Mycelium can have a species-specific ability to absorb and trans-locate metallic elements or metalloids from the mushroom substrate into the mushroom fruiting body. This is because of the specific physiological requirement of some mushroom species that can be impacted by geogenic factors, e.g., low stable Cs $\left({ }^{133} \mathrm{Cs}\right)$ and low-radio $\mathrm{Cs}\left({ }^{137} \mathrm{Cs}\right)$, or relatively high stable $\mathrm{Sr}$ and relatively high-radio $\mathrm{Sr}\left({ }^{90} \mathrm{Sr}\right)$ [17-19], while the reason for metals absorption is note completely elucidated. A well-known example of a hyperaccumulator is the fly agaric (Amanita muscaria), which readily bioaccumulates vanadium found in the metalorganic compound amavadine [20]. A typical example of a mushroom species rich in As is the amethyst deceiver (Laccaria amethystina), which contains dimethylarsinic acid, methylarsonic acid, trimethylarsine oxide, arsenic acid, and arsenobetaine [2122]. Albatrellus and Boletus mushrooms are rich in Se, while for some of the Boletus mushrooms in particular, several seleno-compounds have been identified [23]. Some mushrooms are rich in Ag, while many species are able to efficiently bioaccumulate Ag [24-27]. King bolete (Boletus edulis), bay bolete (Imleria badia), Amanita spp. (A. crocea, A. muscaria, A. submembranacea), and some other species can accumulate Ag in large amounts when they emerge at Ag-contaminated sites (e.g., a Au/ $\mathrm{Cu}$ mine dump or Ag-rich galena smelting [11, 28]), while the species Amanita strobiliformis is a hyper-accumulator of $\mathrm{Ag}$ [29].

Similarly, $\mathrm{Hg}$ is efficiently bio-concentrated by numerous mushrooms, and many species are relatively abundant in mercury even at uncontaminated sites where the $\mathrm{Hg}$ content of the substrate/soil on which the mushroom is growing is very low [30-39]. For instance, the reported mean BCF (the ratio of the content of the element in the cap or stipe to its content in the soil) for the caps of $M$. procera varied from $16 \pm 6$ to $220 \pm 110$ (range 0.52 to 470 ) and that for $B$. edulis varied from $41 \pm 6$ to $130 \pm 39$ (range 13 and 170) [13, 30, 32-34].

Mushrooms are also often rich in metals that are weakly bio-available or in metals that feature as "bioexcluded" by mycelium, but which are abundant in the top layer of soils. Typical examples of this are $\mathrm{Al}, \mathrm{Ca}$, or Fe [12]. Cadmium, chromium, mercury, lead, copper, and zinc are the heavy metals most frequently studied in wild mushrooms [40-45]. There is scarcity of data on mineral composition of the same mushroom species that emerged at geographically distant places that have different soil bedrock geochemistry and environment [46-48].

The aim of this study is to examine the contents of $\mathrm{Ag}, \mathrm{Al}, \mathrm{Ba}, \mathrm{Ca}, \mathrm{Cd}, \mathrm{Co}, \mathrm{Cr}, \mathrm{Cu}, \mathrm{Fe}, \mathrm{Hg}, \mathrm{K}, \mathrm{Mg}, \mathrm{Mn}, \mathrm{Na}$, $\mathrm{Ni}, \mathrm{Pb}, \mathrm{Rb}, \mathrm{Sr}$, and $\mathrm{Zn}$ in widely consumed M. procera, and the soil substrates beneath the mushrooms that were collected from southern and central parts of Poland, and also to assess the mineral interrelationships and bioconcentration potentials of this species. The nutritional benefits and toxicological risk of the minerals determined in $M$. procera are also discussed.

\section{Materials and Methods}

\section{Sampling}

Mature specimens of $M$. procera or parasol mushroom (Macrolepiota procera) and samples (ca. $100 \mathrm{~g}$ ) of top organic and mineral soil horizon $(0-15 \mathrm{~cm})$ beneath the fruiting bodies were collected across the central and southern regions of Poland between 1999 and 2002. The sites surveyed (Jarocin, Lubraniec, Gostyńsko-Włocławskie Forest, Starachowickie Forest, and Poniatowa) are shown in Fig. 1. We also examined archived samples of caps and stipes of 16 fruiting bodies of parasol mushroom collected on the outskirts of the town of Gubin in western Poland in 1994 (Fig. 1), but only cadmium, manganese, lead, copper, and zinc were determined in them.

\section{Elemental Analysis}

Fresh mushrooms, after being cleaned of any visible plant vegetation and soil substrate debris using a plastic knife, were air-dried for several days. Thereafter, each 


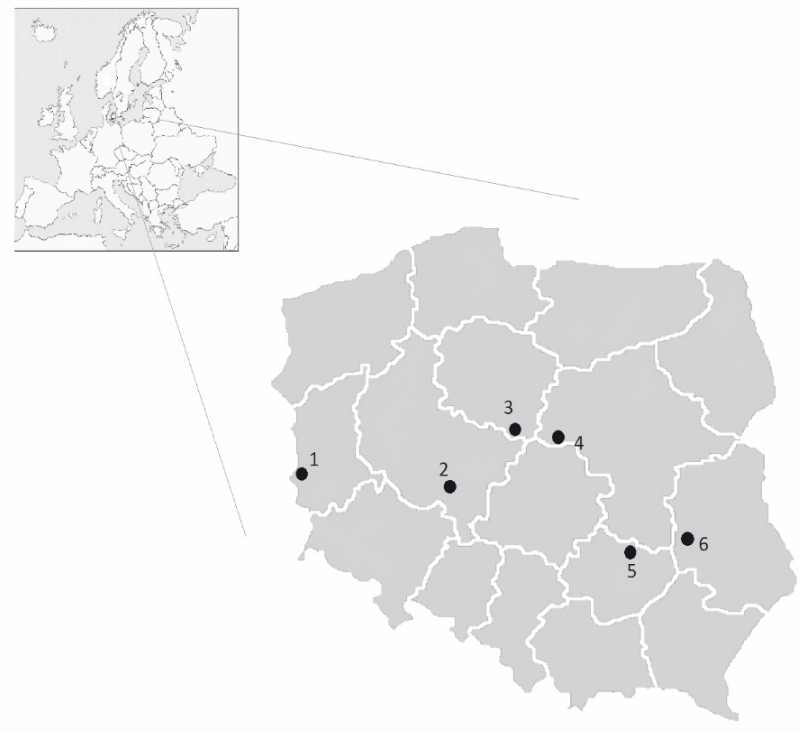

Fig. 1. Location of the sampling sites of field parasol. Abbreviations: Gubin (1), Jarocin (2), Lubraniec (3), Gostyńsko-Włocławskie Forest (4), Starchowickie Forest (5), and Poniatowa (6).

sample of the fruiting body was separated into two parts - the cap and the stipe - and dried at $65^{\circ} \mathrm{C}$ to constant weight. Dried mushroom parts were pulverized in an agate mortar and kept in brand new sealed polyethylene bags under dry conditions. The pulverized sub-samples (400 mg) of caps and stipes were weighed into pressureresistant and analytical quality pro-digestive vessels made of polytetrafluoroethylene (PTFE). The fungal materials were pre-digested for 24 hours with concentrated nitric acid (65\%; Suprapure, Merck; $7 \mathrm{~mL}$ ) at room temperature and further digested under pressure in a MARS 5 (CEM Corp. Matthews, NC, USA) automatic microwave digestion system. The digest, after the addition of an internal standard (yttrium), was diluted to $25 \mathrm{~mL}$ using deionized water and subjected to instrumental analysis [49-50].

The soils were air dried at room temperature under clean conditions for several weeks and next sieved through a pore size of $2 \mathrm{~mm}$ and further dried in an electric oven at $40^{\circ} \mathrm{C}$ to constant weight. Next, the soil sub-samples $(0.5 \mathrm{~g})$ were cold-treated with $20 \%$ nitric acid solution (20 $\mathrm{mL}$ ) for 24 hours in quartz vessels [49-50]. Furthermroe, after the addition of deionized water $(10 \mathrm{~mL})$, the extract was filtered through Whatmann No. 42 filter paper into a polyethylene bottle. After the addition of internal standard (yttrium), the extract was diluted to $50 \mathrm{~mL}$ using deionized water and thereafter subjected to instrumental analysis.

The trace elements (Ag, Al, Ba, Ca, Cd, Co, Cu, Cr, Fe, $\mathrm{K}, \mathrm{Mg}, \mathrm{Mn}, \mathrm{Na}, \mathrm{Ni}, \mathrm{Pb}, \mathrm{Rb}, \mathrm{Sr}$, and $\mathrm{Zn}$ ) were determined by inductively coupled plasma-optical emission spectroscopy (ICP-OES; Optima 2000 DV, Perkin-Elmer, USA) [4950] and $\mathrm{Hg}$ by cold vapor atomic absorption spectrometry (CV-AAS; Mercury analyzer type MA-2000, Nippon Instruments Corporation, Takatsuki, Japan) [51].

\section{Quality Control/Quality Assurance}

These methods of metallic element measurements were validated and controlled on several occasions by the analyses of officially certified reference materials: IAEA 359 cabbage leaves from the International Atomic Energy Agency, and from participation in international calibration trials such as the GESM/Food Euro proficiency testing exercise, the IAEA-338 Proficiency Test of Trace Elements in Lichen, the Aquacon Project 9 Soil Analysis (European Commission Environment Institute), and Oriental tobacco leaves (CTA-OTL-1), tea leaves (INTC-TL-1), and Polish herbal blend (INCT-MPH-2) by the Institute of Nuclear Chemistry and Technology in Warsaw, Poland [49-50]. Discrepancies between certified values and contents quantified were below 10\%. Duplicates and blanks followed with every set of 10 mushroom or soil samples examined. For blank samples no major interferences were found for the elements quantified.

Limits of detection for $\mathrm{Al}, \mathrm{Ba}, \mathrm{Ca}, \mathrm{Cd}, \mathrm{Co}, \mathrm{Cu}, \mathrm{Cr}$, $\mathrm{Fe}, \mathrm{K}, \mathrm{Mg}, \mathrm{Mn}, \mathrm{Na}, \mathrm{Ni}, \mathrm{Pb}, \mathrm{Rb}, \mathrm{Sr}$, and $\mathrm{Zn}$ were between 0.01-0.10 $\mathrm{mg} \mathrm{kg}^{-1}$ dry matter (dm), and $0.005 \mathrm{mg} \mathrm{kg}^{-1} \mathrm{dm}$ for $\mathrm{Hg}$. Coefficients of variation for these measurements on routine runs were well below $10 \%$.

\section{Multivariate Analysis}

All data produced were statistically treated to find possible statistically significant differences between the variables of the Mann-Whitney $U$ test, principal component analysis (PCA), and cluster analysis (CA) (Figs 2-4, Tables 2 and 3) [41]. The computer software package Statistica version 8.0 was used for statistical analysis of data.

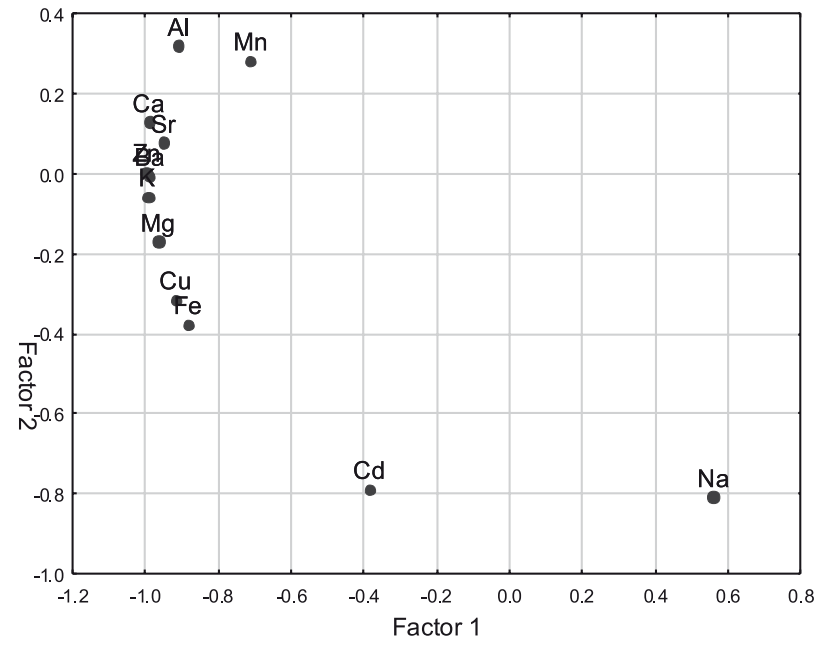

Fig. 2. Plot of loadings (unrotated) based on the content of metallic elements in caps of Macrolepiota procera in spaces of the first and second factors. 


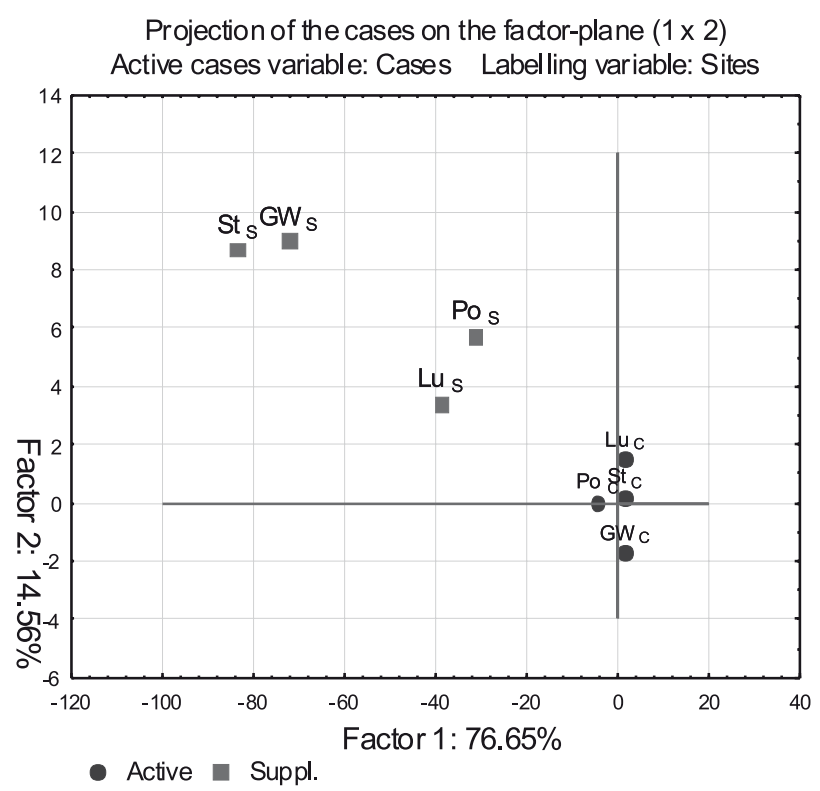

Fig. 3. Projection of the data on caps of Macrolepiota procera and forest soil substratum collected from four sampling sites set on the factor 1 (PC 1) and factor 2 (PC 2) planes.

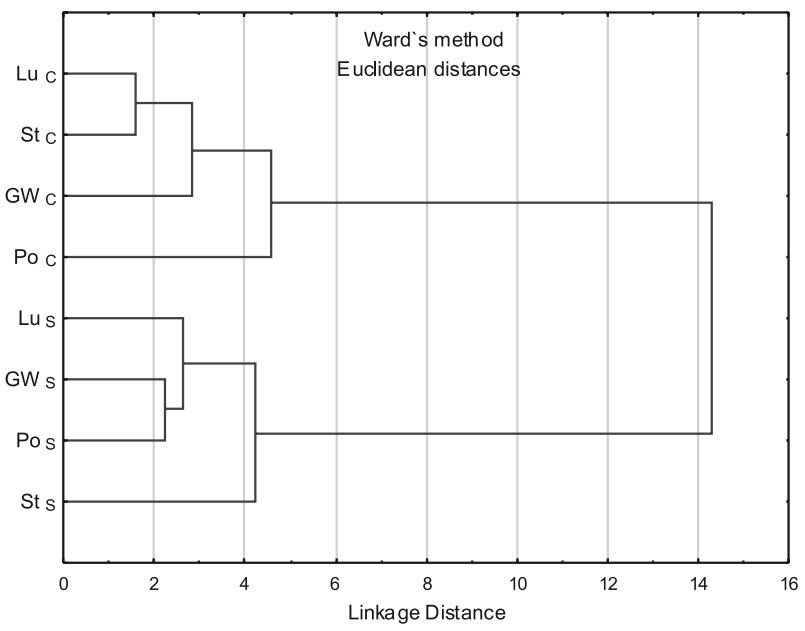

Fig. 4. Bundle diagram of similarity of minerals composition between caps of Macrolepiota procera and forest soil substratum from four spatially distant sites ( $\mathrm{Lu}$ - Lubraniec, GW Gostyńsko-Włocławskie Forest, St - Starchowickie Forest, Po - Poniatowa, $\mathrm{C}$ - caps, $\mathrm{S}$ - soil).

\section{Results and Discussion}

The metal contents in caps and stipes of M. procera and the soils as well as the values of the quotient of metal contents in cap to stipe $\left(\mathrm{Q}_{\mathrm{CIS}}\right)$ and in cap or stipe to contents in soil substratum (BCF, or bioconcentration factor) are given in Table 1 and in Annexes 1 and 2. These data are for 99 specimens of $M$. procera $\mathrm{m}$ collected from six geographically distant regions of central, southwest, and southeast Poland. Some metallic elements in this study were determined in mushrooms and soils collected in one $(\mathrm{Rb})$, two $(\mathrm{Co}, \mathrm{Cr}, \mathrm{Hg}, \mathrm{Pb})$, three $(\mathrm{Ag})$, or four to six sites (other metals), respectively (Annexes 1 and 2).

\section{Essential Metals: Major Minerals (K, Mg, Ca)}

Among the essential macro-elements determined, potassium (K) was found in highest amounts in $M$. procera. Depending on the site, $\mathrm{K}$ content varied between $32,000 \pm 7,000$ and $49,000 \pm 3,000$ (total range 18,000$52,000) \mathrm{mg} \mathrm{kg}^{-1} \mathrm{dm}$. The caps were on average about two-fold richer in $\mathrm{K}$ than the stipes. Potassium content of caps and stipes as well as the value of $\mathrm{Q}_{\mathrm{C} / \mathrm{S}}$ for this metal varied significantly between the sampling sets (year of collection) of mushrooms ( $<<0.05$; Mann-Whitney $U$ test; Table 1). $M$. procera is characterized by a high potential to bioconcentrate potassium. The BCF (also called enrichment or transfer factor) of $\mathrm{K}$ ranged from 140 to 740 for caps and from 76-750 for stipes of 88 specimens collected from four of the sites surveyed. BCF is a unitless parameter and is calculated as a quotient of the content of the metal determined in the fruiting body or its morphological part in relation to metal content of the substratum in which the mycelium lives (soil, wood, compost). All analytical data are expressed on a dryweight basis. The mean $\mathrm{K}$ content of the soil substratum to $M$. procera varied between $0.10 \pm 0.03$ and $0.15 \pm 0.06$ $\mathrm{mg} \mathrm{kg}{ }^{-1} \mathrm{dm}$.

Potassium content in caps of $M$. procera is followed by $\mathrm{Mg}$ and then $\mathrm{Ca}$. Mean magnesium contents in caps of four sites varied from $1,000 \pm 100$ to $2,500 \pm 100$ (range $650-2,700) \mathrm{mg} \mathrm{kg}^{-1} \mathrm{dm}$, while the mean Ca content varied between $130 \pm 75$ and $440 \pm 140$ (range 63-850) mg kg-1 $\mathrm{dm}^{2}$ (Table 1). Calcium is usually more abundant in stipes than in caps of this fungus, while $\mathrm{Mg}$ is usually more in the caps (Table 1). As in the case of $\mathrm{K}$, the contents of $\mathrm{Mg}$ and $\mathrm{Ca}$ in $M$. procera varied statistically, depending on the sites surveyed $(0.05<\mathrm{p}<0.01$; Mann-Whitney $U$ test $)$. The contents of magnesium in soil (substratum to Parasol Mushroom fruiting bodies) varied from $89 \pm 20$ to $190 \pm 40$; and $\mathrm{Ca}$ from $400 \pm 58$ to $1,300 \pm 190 \mathrm{mg} \mathrm{kg}^{-1} \mathrm{dm}$. Up-take of $\mathrm{Mg}$ and $\mathrm{Ca}$ by M. procera, when assessed from the $\mathrm{BCF}$ values, decreased as content of $\mathrm{Mg}$ and $\mathrm{Ca}$ in topsoil increased. Nevertheless, the relatively high contents of $\mathrm{Mg}$ and $\mathrm{Ca}$ in the soils - in spite of the lower availability or regulated up-take by the mushroom - resulted in the abundance of these metals in the fruiting bodies, as noted for Gostyńsko-Włocławskie Forest $(\mathrm{Mg})$ and the Poniatowa site (Ca) (Table 1).

\section{Essential Metals: Trace Constituents ( $\mathrm{Zn}, \mathrm{Cu}, \mathrm{Fe}, \mathrm{Mn}, \mathrm{Na}, \mathrm{Cr}, \mathrm{Co}$ )}

Among $\mathrm{Zn}, \mathrm{Cu}, \mathrm{Fe}, \mathrm{Mn}, \mathrm{Na}, \mathrm{Cr}$, and $\mathrm{Co}$, which are essential to mammals, some of them $(\mathrm{Zn}, \mathrm{Cu}, \mathrm{Fe}, \mathrm{Mn}$, and $\mathrm{Na}$ ) are also essential to fungi [52]. These five metals were determined in the caps in contents ranging from $10 \pm 7 \mathrm{mg}$ $\mathrm{kg}^{-1} \mathrm{dm}(\mathrm{Na})$ to $640 \pm 36 \mathrm{mg} \mathrm{kg}^{-1} \mathrm{dm}(\mathrm{Zn})$, while $\mathrm{Cr}$ and $\mathrm{Co}$ 


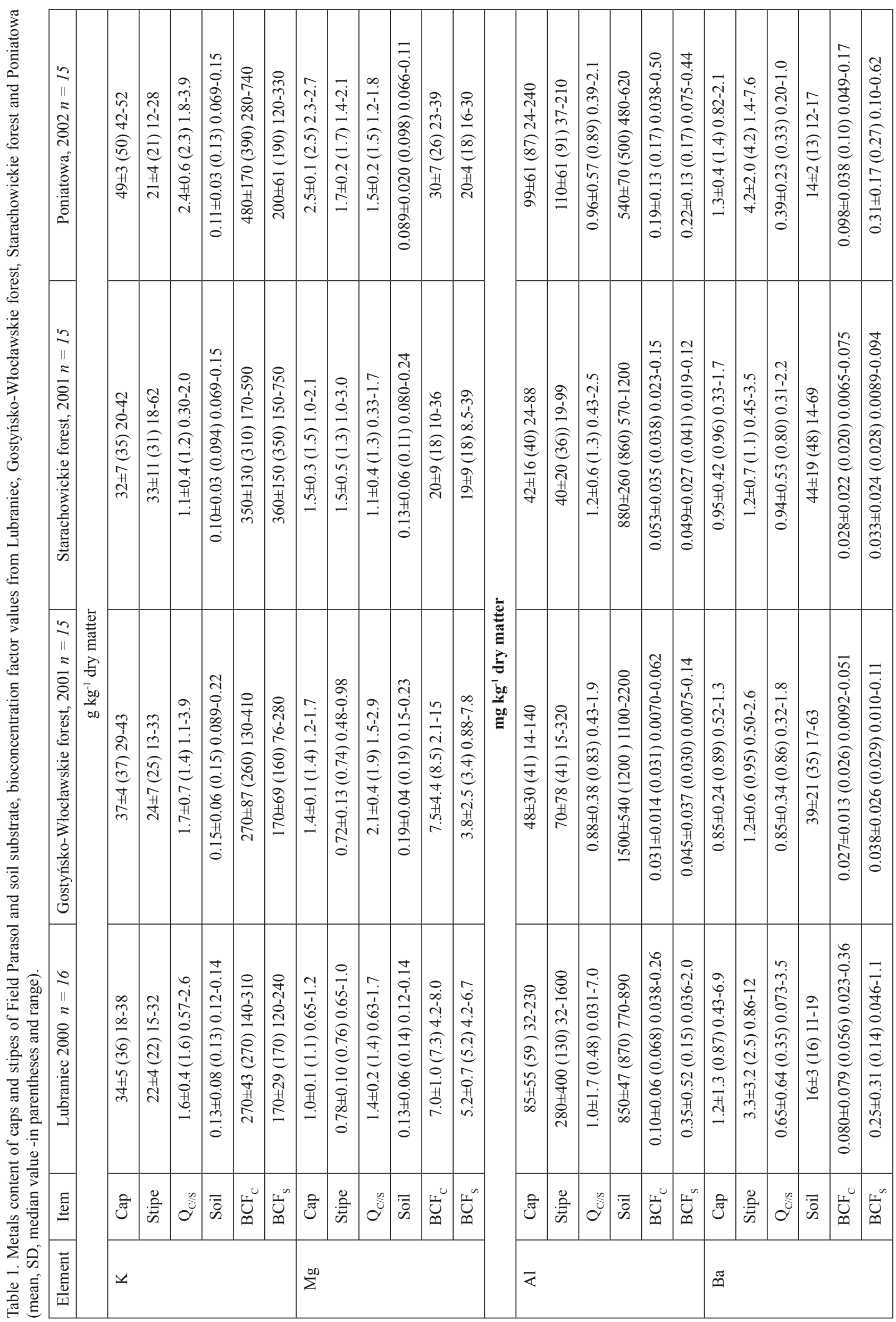




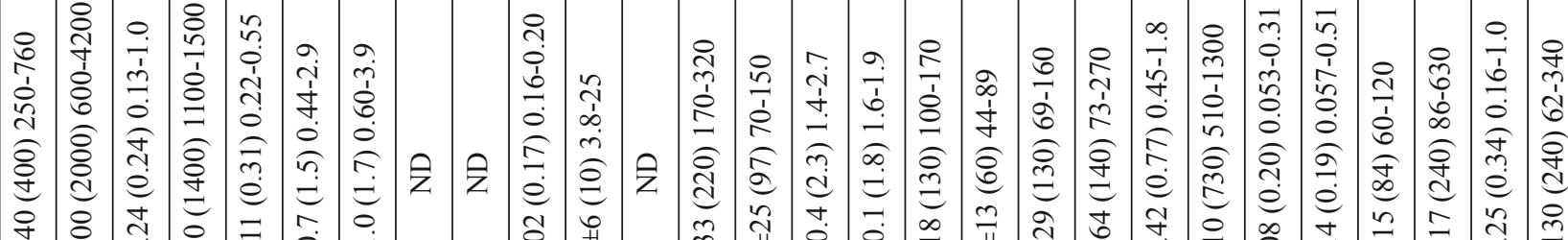

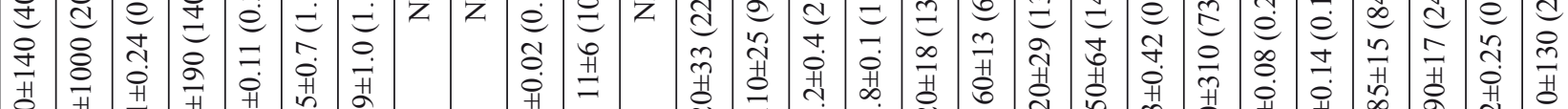

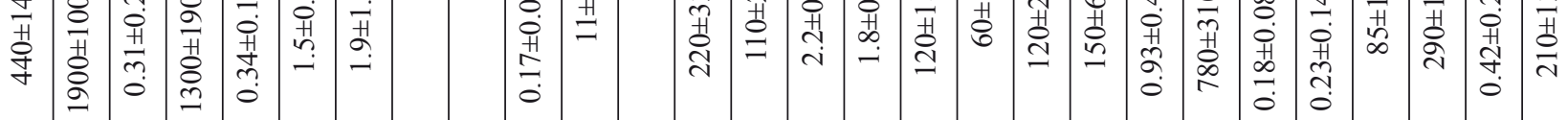

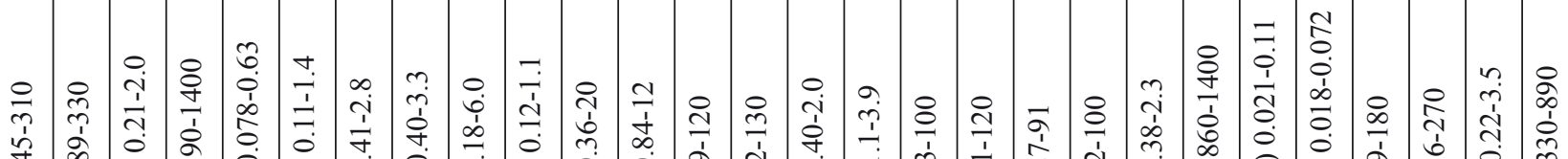

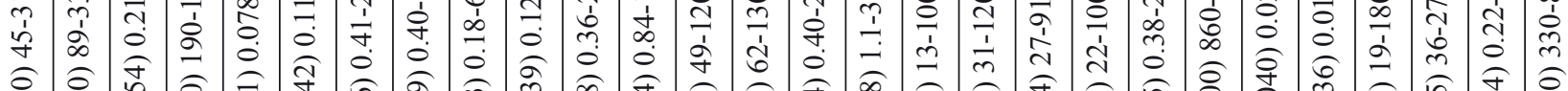

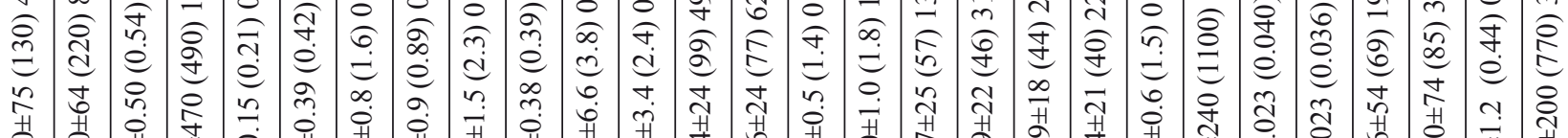

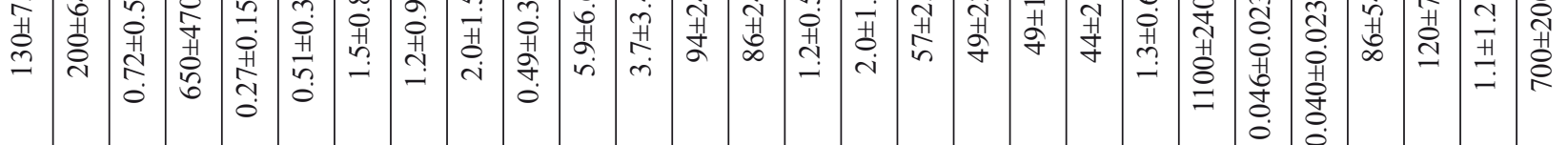

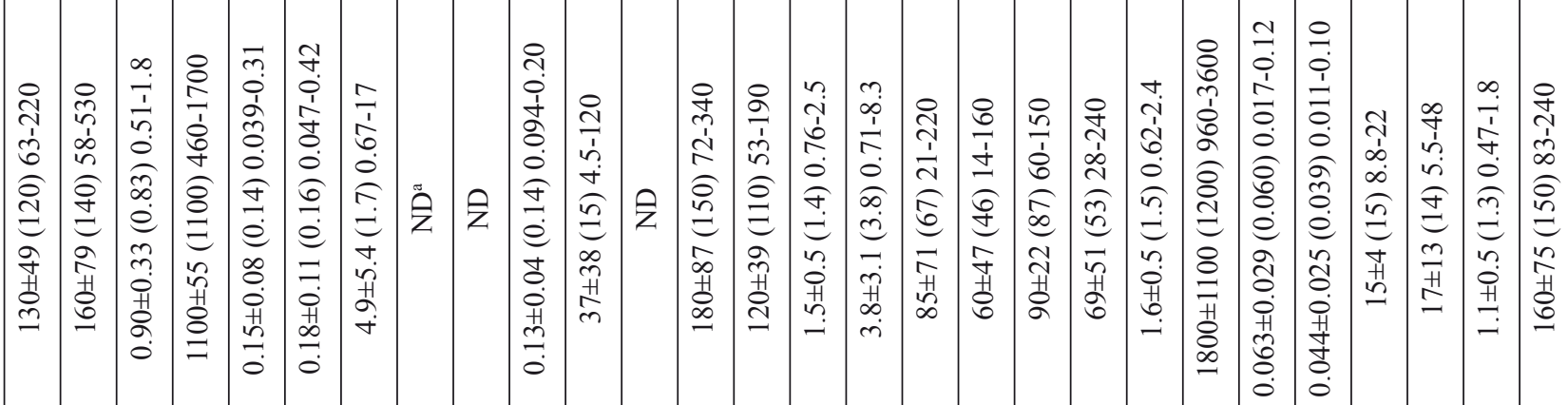

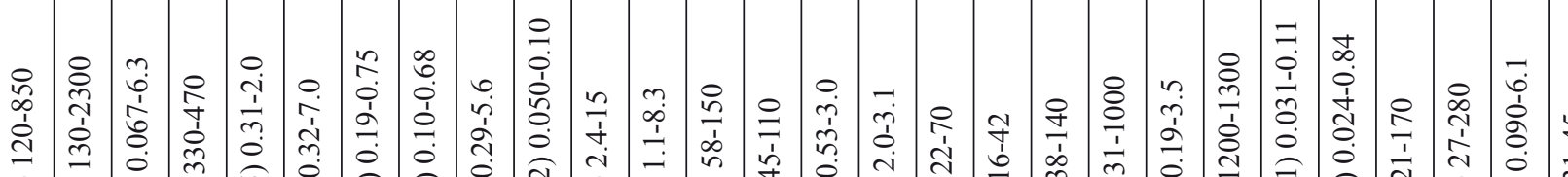

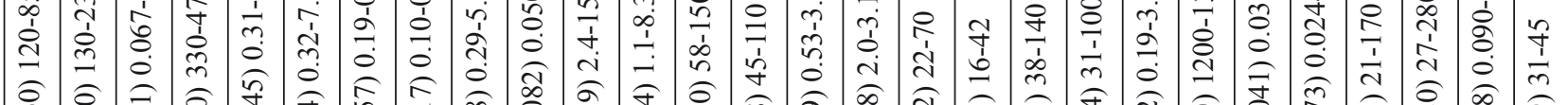

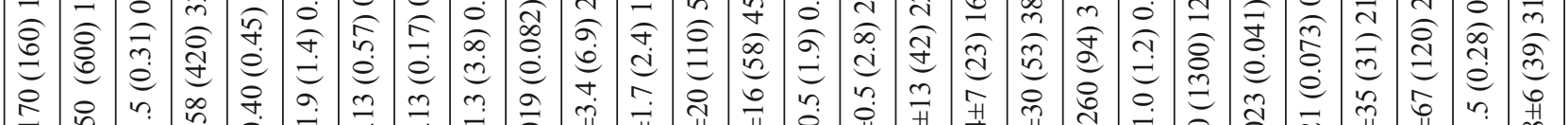

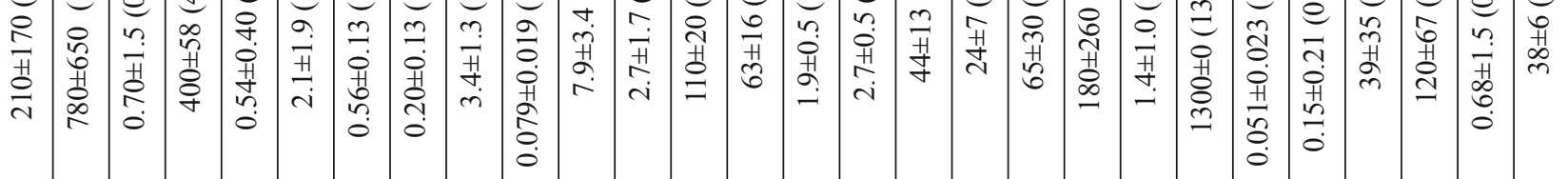

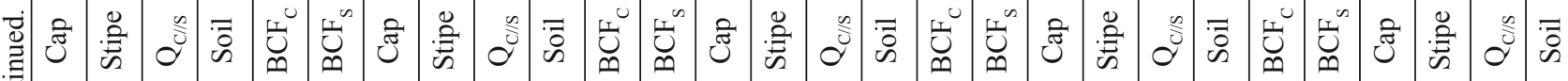

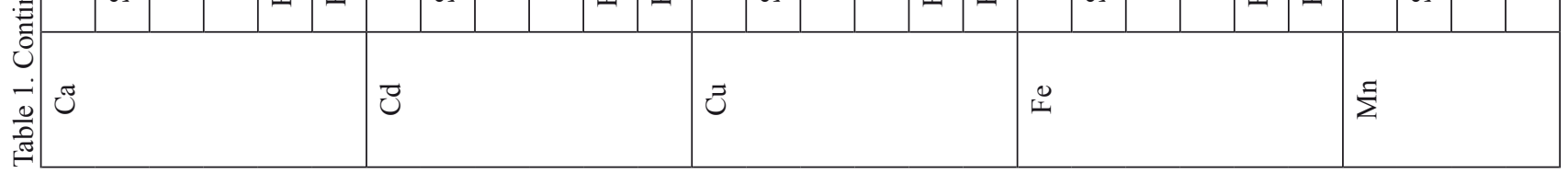




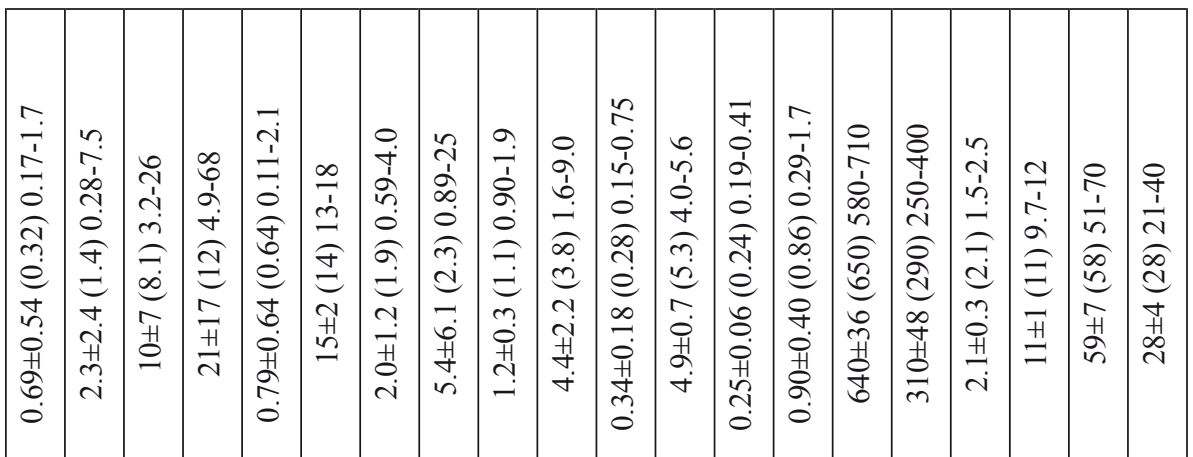

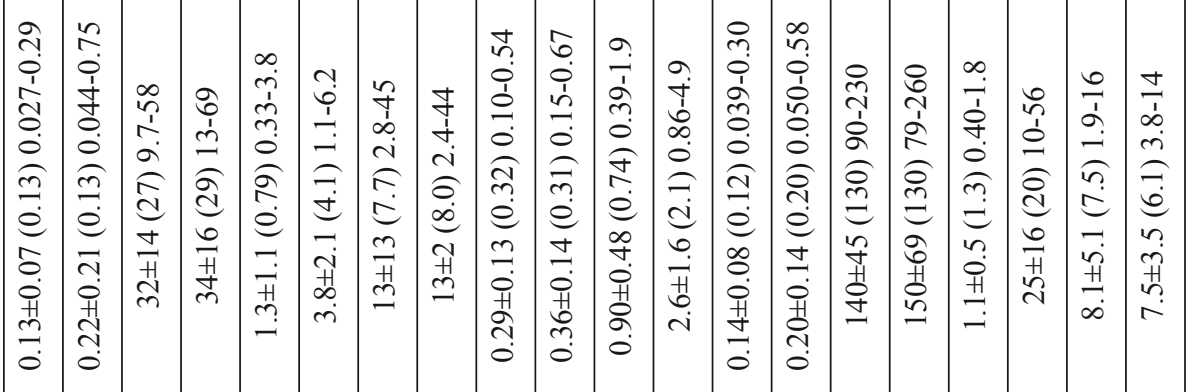

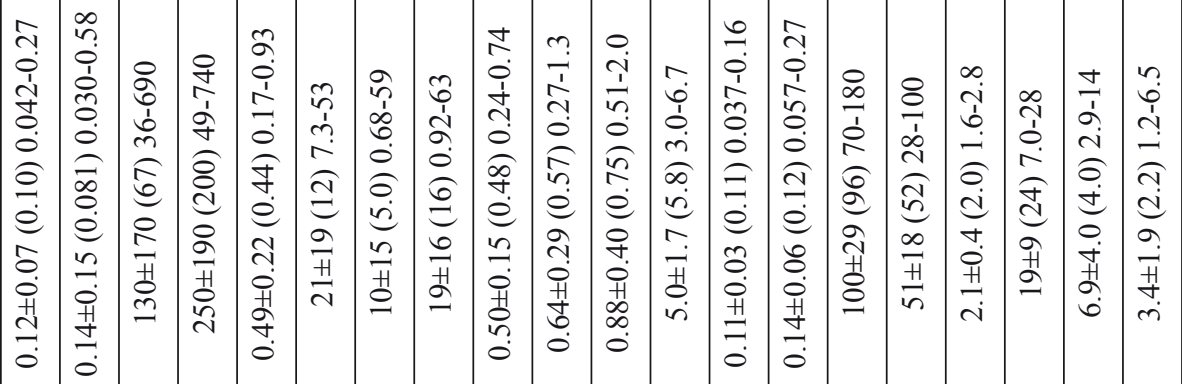

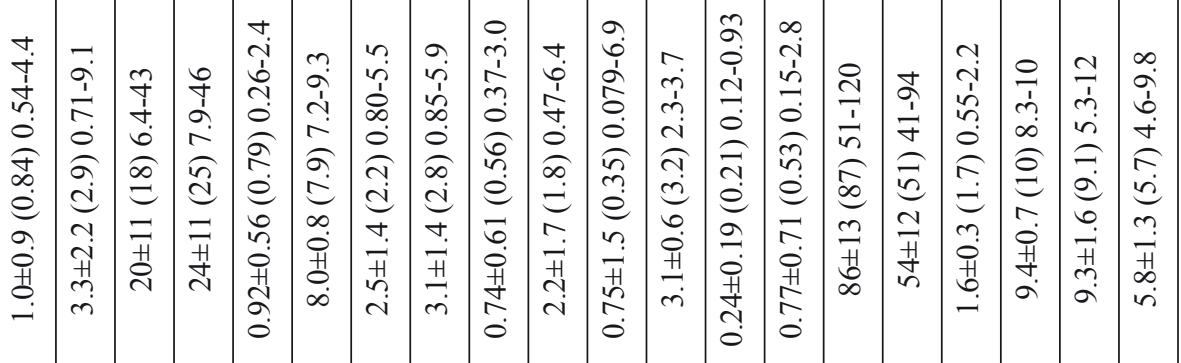

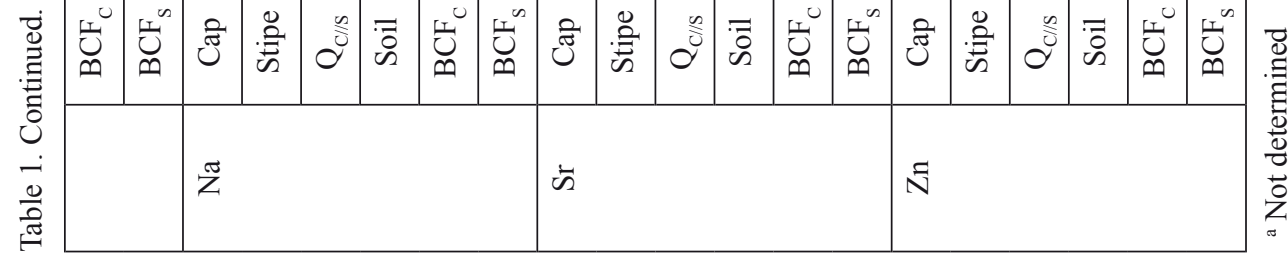


ANNEX 1. Metals contents of caps and stipes of field parasol and soil substrate, bioconcentration factor values from Lubraniec and Poniatowa ( $\mathrm{mg} \mathrm{kg}^{-1}$ dry mass; mean, $\mathrm{SD}^{\mathrm{a}}$, median value - in parentheses and range).

\begin{tabular}{|c|c|c|c|}
\hline \multirow{2}{*}{ Element } & \multirow{2}{*}{ Item } & \multicolumn{2}{|c|}{ Site } \\
\hline & & Lubraniec $2000 n=16$ & Poniatowa, $2002 n=15$ \\
\hline \multirow[t]{6}{*}{$\mathrm{Ag}$} & Cap & $3.8 \pm 1.3(3.2) 1.3-5.9$ & $16 \pm 7(13) 5.4-31$ \\
\hline & Stipe & $1.6 \pm 0.8(1.4) 1.0-4.1$ & $5.7 \pm 2.8(5.3) 1.5-10$ \\
\hline & $\mathrm{Q}_{\mathrm{C} / \mathrm{s}}^{\mathrm{b}}$ & $2.4 \pm 0.8(2.4) 0.31-3.2$ & $2.9 \pm 0.7(2.9) 1.6-4.5$ \\
\hline & Soil & $0.0084 \pm 0.0011(0.0086) 0.007-0.010$ & $0.031 \pm 0.020(0.036) 0.011-0.056$ \\
\hline & $\mathrm{BCF}_{\mathrm{c}}$ & $420 \pm 130(410) 190-680$ & $730 \pm 630(470) 130-2600$ \\
\hline & $\mathrm{BCF}_{\mathrm{s}}$ & $200 \pm 120(160) 110-610$ & $260 \pm 210(190) 28-890$ \\
\hline \multirow[t]{6}{*}{ Co } & Cap & $0.050 \pm 0.033(0.05) 0.01-0.10$ & $0.22 \pm 0.07(0.20) 0.10-0.40$ \\
\hline & Stipe & $0.14 \pm 0.11(0.10) 0.025-0.49$ & $0.36 \pm 0.12(0.37) 0.20-0.65$ \\
\hline & $\mathrm{Q}_{\mathrm{C} / \mathrm{s}}$ & $0.50 \pm 0.41(0.34) 0.026-1.2$ & $0.66 \pm 0.31(0.61) 0.23-1.6$ \\
\hline & Soil & $0.39 \pm 0.03(0.41) 0.34-0.42$ & $0.34 \pm 0.14(0.35) 0.21-0.56$ \\
\hline & $\mathrm{BCF}_{\mathrm{c}}$ & $0.13 \pm 0.09(0.13) 0.0054-0.27$ & $0.71 \pm 0.29(0.82) 0.18-1.2$ \\
\hline & $\mathrm{BCF}_{\mathrm{s}}$ & $0.37 \pm 0.35(0.25) 0.062-1.5$ & $1.2 \pm 0.6(1.2) 0.35-2.2$ \\
\hline \multirow[t]{6}{*}{$\mathrm{Cr}$} & Cap & $0.26 \pm 0.16(0.24) 0.13-0.78$ & $1.3 \pm 0.1(1.3) 1.0-1.6$ \\
\hline & Stipe & $0.58 \pm 0.67(0.30) 0.12-2.7$ & $0.98 \pm 0.22(0.94) 0.75-1.6$ \\
\hline & $\mathrm{Q}_{\mathrm{C} / \mathrm{s}}$ & $0.87 \pm 0.69(0.78) 0.10-2.7$ & $1.4 \pm 0.3(1.4) 0.74-1.8$ \\
\hline & Soil & $1.4 \pm 0.1(1.5) 1.3-1.5$ & $0.76 \pm 0.14(0.69) 0.63-0.92$ \\
\hline & $\mathrm{BCF}_{\mathrm{c}}$ & $0.18 \pm 0.11(0.16) 0.088-0.52$ & $1.8 \pm 0.4(1.8) 1.1-2.5$ \\
\hline & $\mathrm{BCF}_{\mathrm{s}}$ & $0.41 \pm 0.50(0.20) 0.083-2.0$ & $1.3 \pm 0.2(1.3) 0.94-1.7$ \\
\hline \multirow[t]{6}{*}{$\mathrm{Hg}$} & Cap & $2.1 \pm 0.6(2.0) 1.3-3.5$ & $3.1 \pm 0.9(2.9) 1.8-4.6$ \\
\hline & Stipe & $0.98 \pm 0.28(0.87) 0.67-1.7$ & $1.5 \pm 0.4(1.5) 0.63-2.7$ \\
\hline & $\mathrm{Q}_{\mathrm{C} / \mathrm{s}}$ & $2.2 \pm 0.7(2.1) 1.5-4.5$ & $2.1 \pm 0.5(2.1) 1.3-2.9$ \\
\hline & Soil & $0.13 \pm 0.02(0.13) 0.11-0.16$ & $0.047 \pm 0.010(0.046) 0.035-0.063$ \\
\hline & $\mathrm{BCF}_{\mathrm{c}}$ & $16 \pm 6(15) 8.3-31$ & $69 \pm 23(62) 29-120$ \\
\hline & $\mathrm{BCF}_{\mathrm{s}}$ & $7.6 \pm 2.8(6.8) 4.3-15$ & $34 \pm 9(34) 10-46$ \\
\hline \multirow[t]{6}{*}{$\mathrm{Ni}$} & Cap & $0.86 \pm 0.22(0.84) 0.60-1.5$ & $0.29 \pm 0.47(0.01) 0.01-1.3$ \\
\hline & Stipe & $1.3 \pm 0.6(1.2) 0.52-2.9$ & $0.39 \pm 0.95(0.05) 0.01-3.6$ \\
\hline & $\mathrm{Q}_{\mathrm{C} / \mathrm{s}}$ & $0.81 \pm 0.60(0.68) 0.23-2.8$ & $0.84 \pm 0.64(1.0) 0.41-2.6$ \\
\hline & Soil & $1.0 \pm 0.1(1.0) 0.85-1.1$ & $0.80 \pm 0.06(0.79) 0.75-0.89$ \\
\hline & $\mathrm{BCF}_{\mathrm{c}}$ & $0.87 \pm 0.21(0.83) 0.57-1.4$ & $0.36 \pm 0.59(0.01) 0.0056-1.6$ \\
\hline & $\mathrm{BCF}_{\mathrm{s}}$ & $1.4 \pm 0.8$ (1.2) $0.50-3.4$ & $0.49 \pm 1.2(0.067) 0.0056-4.4$ \\
\hline \multirow[t]{6}{*}{$\mathrm{Pb}$} & Cap & $2.3 \pm 0.7(2.2) 1.6-4.4$ & $5.9 \pm 1.7(5.2) 3.6-8.9$ \\
\hline & Stipe & $1.9 \pm 1.3(1.4) 0.50-5.1$ & $3.7 \pm 0.9(3.8) 1.9-5.5$ \\
\hline & $\mathrm{Q}_{\mathrm{C} / \mathrm{S}}$ & $1.9 \pm 0.9$ (1.9) $0.44-4.0$ & $1.7 \pm 0.7$ (1.6) $0.81-3.1$ \\
\hline & Soil & $12 \pm 1(12) 10-13$ & $8.8 \pm 1.4(7.9) 7.4-11$ \\
\hline & $\mathrm{BCF}_{\mathrm{c}}$ & $0.20 \pm 0.06(0.20) 0.13-0.37$ & $0.70 \pm 0.20(0.65) 0.38-1.1$ \\
\hline & $\mathrm{BCF}_{\mathrm{s}}$ & $0.17 \pm 0.14(0.13) 0.041-0.52$ & $0.43 \pm 0.12(0.44) 0.21-0.59$ \\
\hline
\end{tabular}


ANNEX 1. Continued.

\begin{tabular}{|c|c|c|c|}
\hline $\mathrm{Rb}$ & Cap & $\mathrm{ND}^{\mathrm{c}}$ & $38 \pm 7(37) 27-53$ \\
\cline { 2 - 4 } & Stipe & ND & $21 \pm 37(12) 6.8-150$ \\
\cline { 2 - 4 } & $\mathrm{QC/s}$ & $\mathrm{ND}$ & $3.3 \pm 1.5(3.3) 0.22-6.4$ \\
\cline { 2 - 4 } & Soil & $\mathrm{ND}$ & $0.45 \pm 0.21(0.39) 0.25-0.71$ \\
\cline { 2 - 4 } & $\mathrm{BCF}_{\mathrm{c}}$ & $\mathrm{ND}$ & $100 \pm 48(110) 44-180$ \\
\cline { 2 - 4 } & $\mathrm{BCF}_{\mathrm{S}}$ & $\mathrm{ND}$ & $45 \pm 50(36) 12-220$ \\
\hline
\end{tabular}

${ }^{a}$ SD standard deviation

${ }^{b} Q_{c / s}$ values of the quotient of metal contents in cap to stipe

${ }^{\mathrm{c}}$ Not determined

(determined for samples from two sites only) were below $1 \mathrm{mg} \mathrm{kg}^{-1} \mathrm{dm}$, on average (Annex 1).

The mean content of $\mathrm{Zn}$ in caps of M. procera is 200 $\mathrm{mg} \mathrm{kg} \mathrm{dm}^{-1}$, followed by $170,81,48$, and $45 \mathrm{mg} \mathrm{kg}^{-1} \mathrm{dm}$ for $\mathrm{Cu}, \mathrm{Fe}, \mathrm{Na}$, and $\mathrm{Mg}$, respectively. The corresponding values (arithmetic mean) for stipes are $120 \mathrm{mg} \mathrm{kg}^{-1} \mathrm{dm}_{\text {for }}$ $\mathrm{Zn}$ and $110 \mathrm{mg} \mathrm{kg}^{-1} \mathrm{dm}$ for $\mathrm{Cu}, \mathrm{Fe}$, and $\mathrm{Mn}$, and $81 \mathrm{mg} \mathrm{kg}^{-1}$ $\mathrm{dm}$ for $\mathrm{Na}$. The contents of $\mathrm{Mn}, \mathrm{Na}$, and Fe showed that they appeared to be more abundant in the stipes than in the caps of $M$. procera. Nevertheless, the $\mathrm{Q}_{\mathrm{C} / \mathrm{S}}$ values of these metals varied significantly depending on the site surveyed (Table 1).

These metals occurred in caps in contents that were comparable $(p>0.05)$ for some sites while there were significant differences for some other sites $(p<0.05$; Mann Whitney $U$ test), e.g., higher content of $\mathrm{Cu}, \mathrm{Fe}, \mathrm{Mg}$, and $\mathrm{Zn}$, but lower for $\mathrm{Na}$ in individuals from the Poniatowa site (Table 1). Considering the mean values for caps at the sites surveyed, the contents varied for $\mathrm{Zn}$ from $86 \pm 13$ to $640 \pm 36$ (range $51-710$ ) $\mathrm{mg} \mathrm{kg}^{-1} \mathrm{dm}_{\text {followed }}$ by $\mathrm{Cu}$ with mean values ranging from $94 \pm 24$ to $280 \pm 73$ (range 49-440) $\mathrm{mg} \mathrm{kg}^{-1} \mathrm{dm}$. The caps were about twice more abundant in $\mathrm{Zn}$ and $\mathrm{Cu}$ than the stipes (Table 1). The soil substrates from Gostyńsko-Włocławskie Forest and Starachowickie Forest contained twice more $\mathrm{Zn}$ than the soils from the Lubraniec and Poniatowa sites, while those from Gostyńsko-Włocławskie Forest were also about twice richer in $\mathrm{Cu}(0.05<\mathrm{p}<0.01)$. There is an apparent variation in the availability of $\mathrm{Zn}$ and $\mathrm{Cu}$ to $M$. procera between the sites surveyed, as can be seen from the values of the BCF. Both $\mathrm{Zn}$ and $\mathrm{Cu}$ are well bioconcentrated by $M$. procera, and their BCF values varied between the sites, on average from about 5 to 60 for $\mathrm{Zn}$ and from 40 to 120 for $\mathrm{Cu}$. At the Poniatowa site $\mathrm{Zn}$ and $\mathrm{Cu}$ were more bioavailable from soil than elsewhere in this study.

The mean Fe content in caps varied from $49 \pm 18$ to $120 \pm 29$ (range 27-160) $\mathrm{mg} \mathrm{kg}^{-1} \mathrm{dm}$, followed by $\mathrm{Mn}$, which varied from $15 \pm 4$ to $86 \pm 54$ (range 8.8-180), and then $\mathrm{Na}$, which varied from $10 \pm 7$ to $130 \pm 170$ (range 3.2-690) $\mathrm{mg} \mathrm{kg}^{-1} \mathrm{dm}$ (Table 1). Iron was abundant in the soils, and also to some degree in the caps and stipes - and Fe can be considered to be bioexcluded by this fungus since its $\mathrm{BCF}$ values were $<0.5$. Similar to $\mathrm{Cu}$ and $\mathrm{Zn}, \mathrm{Fe}$ was more bioavailable at the Poniatowa site, where the soil Fe contents were significantly lower ( $<<0.01$; MannWhitney $U$ test) when compared to other sites. Mn and $\mathrm{Na}$ content of the upper soil layer varied highly between the sites $(0.001<p<0.01$; Table 1$)$, and Mn was usually bioexcluded, while $\mathrm{Na}$ was bioconcentrated in fruiting bodies (median BCF of 1.9-7.7 for caps).

Cobalt and chromium were determined only in soils and mushrooms from the Lubraniec and Poniatowa sites (Annex 2). The median contents of these metals in caps varied significantly $(\mathrm{p}<0.01)$ between the sites. The mean Co content values ranged from $0.050 \pm 0.033$ to $0.22 \pm 0.07$ (range 0.01-0.40) $\mathrm{mg} \mathrm{kg}^{-1} \mathrm{dm}$, and for $\mathrm{Cr}$ between $0.26 \pm 0.16$ and $1.3 \pm 0.1$ (range 0.13-1.6) $\mathrm{mg} \mathrm{kg}^{-1} \mathrm{dm}$, while the corresponding values for stipes were smaller. The availability of these two trace metals to $M$. procera also varied between the sites investigated. The results of this study indicate that $\mathrm{Co}$ is bioexcluded by the parasol mushroom. For $\mathrm{Cr}$, the $\mathrm{BCF}$ for specimens from the Poniatowa site was around 1.5, while the corresponding value for the Lubraniec site is much lower.

\section{Some other Metals: Trace Constituents (Al, Ba, Ni, Rb, Sr)}

Aluminum is bio-excluded by $M$. procera $(\mathrm{BCF}<0.5)$. Nevertheless, Al was found to be relatively abundant in the caps with the mean values of the sites investigated ranging from $42 \pm 16$ to $99 \pm 61$ (total $14-240$ ) $\mathrm{mg} \mathrm{kg}^{-1} \mathrm{dm}$. In spite of the low BCF, the relative abundance of $\mathrm{Al}$ in the fruiting bodies may be a result of its abundance in the soil (between 500 and 1,200 $\mathrm{mg} \mathrm{kg}^{-1} \mathrm{dm}$, on average; Table 1), and there may be a competitive co-absorption of $\mathrm{Al}$ with other metals.

Barium and strontium contents in the soils for the four sites varied from $14 \pm 2$ to $44 \pm 19$ (range 11-69) $\mathrm{mg} \mathrm{kg}{ }^{-1} \mathrm{dm}$, and from 2.6 \pm 1.6 to $5.0 \pm 1.7$ (range $0.86-67$ ) $\mathrm{mg} \mathrm{kg}^{-1} \mathrm{dm}$, respectively (Table 1). Barium and strontium are bioexcluded by $M$. procera. In caps they occurred in contents between $0.85 \pm 0.24$ and $1.3 \pm 0.4$ (range 0.33-6.9) $\mathrm{mg} \mathrm{Ba} \mathrm{kg}{ }^{-1} \mathrm{dm} \mathrm{m}$, and between $0.29 \pm 0.13$ and $1.2 \pm 0.3$ (range 0.10-3.0) $\mathrm{mg} \mathrm{Sr} \mathrm{kg}^{-1} \mathrm{dm}$. Both metals were usually more enriched in stipes than in the caps of fruiting bodies of this fungus. 
ANNEX 2. Metals contents of caps and stipes of field parasol and soil substrate and bioconcentration factor values (mg kg-1 $\mathrm{dm}^{\text {; }}$ mean $\pm \mathrm{SD}$ and median value - in parentheses and range).

\begin{tabular}{|c|c|c|c|}
\hline \multirow{2}{*}{ Element } & \multirow{2}{*}{ Item } & \multicolumn{2}{|c|}{ Site } \\
\hline & & Gubin, $1994 n=16$ & Jarocin, $1999 n=12$ \\
\hline \multirow[t]{6}{*}{$\mathrm{Ag}$} & Cap & $\mathrm{ND}^{\mathrm{a}}$ & $1.2 \pm 0.7$ (1.2) $0.40-3.1$ \\
\hline & Stipe & ND & $1.5 \pm 0.6(1.4) 0.52-2.5$ \\
\hline & $\mathrm{Q}_{\mathrm{C} / \mathrm{S}}^{\mathrm{b}}$ & ND & $0.77 \pm 0.42(0.70) 0.49-2.0$ \\
\hline & Soil & ND & $0.062 \pm 0.007$ (0.063) 0.054-0.069 \\
\hline & $\mathrm{BCF}_{\mathrm{C}}$ & ND & $19 \pm 14(19) 6.6-57$ \\
\hline & $\mathrm{BCF}_{\mathrm{S}}$ & ND & $25 \pm 10(26) 8.6-41$ \\
\hline \multirow[t]{6}{*}{$\mathrm{Ba}$} & Cap & ND & $0.57 \pm 0.19(0.58) 0.11-0.83$ \\
\hline & Stipe & ND & $0.98 \pm 0.70(0.90) 0.16-2.2$ \\
\hline & $\mathrm{Q}_{\mathrm{C} / \mathrm{S}}$ & ND & $0.92 \pm 0.55(0.75) 0.18-2.5$ \\
\hline & Soil & ND & $47 \pm 1(47) 47-48$ \\
\hline & $\mathrm{BCF}_{\mathrm{C}}$ & ND & $0.012 \pm 0.004(0.012) 0.0047-0.018$ \\
\hline & $\mathrm{BCF}_{\mathrm{S}}$ & ND & $0.021 \pm 0.015(0.019) 0.0033-0.047$ \\
\hline \multirow[t]{6}{*}{$\mathrm{Cd}$} & Cap & $3.2 \pm 2.4(2.2) 1.3-11$ & $1.1 \pm 0.5(0.97) 0.57-2.3$ \\
\hline & Stipe & $1.2 \pm 1.0(0.50) 0.50-3.3$ & $0.47 \pm 0.33(0.37) 0.23-1.4$ \\
\hline & $\mathrm{Q}_{\mathrm{C} / \mathrm{s}}$ & $4.6 \pm 5.0(3.7) 0.69-22$ & $2.5 \pm 0.7(2.6) 1.6-4.4$ \\
\hline & Soil & ND & $0.20 \pm 0.01(0.20) 0.20-0.21$ \\
\hline & $\mathrm{BCF}_{\mathrm{C}}$ & ND & $5.6 \pm 2.6(4.7) 2.8-12$ \\
\hline & $\mathrm{BCF}_{\mathrm{S}}$ & ND & $2.3 \pm 1.7(1.8) 1.1-7.4$ \\
\hline \multirow[t]{6}{*}{ Co } & Cap & ND & $0.044 \pm 0.020(0.040) 0.020-0.090$ \\
\hline & Stipe & ND & $0.049 \pm 0.024(0.048) 0.024-0.11$ \\
\hline & $\mathrm{Q}_{\mathrm{C} / \mathrm{S}}$ & ND & $0.94 \pm 0.29(0.92) 0.54-1.5$ \\
\hline & Soil & ND & $0.80 \pm 0.01(0.80) 0.78-0.81$ \\
\hline & $\mathrm{BCF}_{\mathrm{C}}$ & ND & $0.055 \pm 0.025(0.047) 0.021-0.11$ \\
\hline & $\mathrm{BCF}_{\mathrm{S}}$ & ND & $0.061 \pm 0.029(0.069) 0.030-0.14$ \\
\hline \multirow[t]{6}{*}{$\mathrm{Cr}$} & Cap & ND & $0.14 \pm 0.03(0.13) 0.10-0.21$ \\
\hline & Stipe & ND & $0.16 \pm 0 ; 07$ (0.18) 0.088-0.32 \\
\hline & $\mathrm{Q}_{\mathrm{C} / \mathrm{s}}$ & ND & $0.96 \pm 0.41(0.74) 0.42-1.7$ \\
\hline & Soil & ND & $2.0 \pm 0.01(2.0) 1.9-2.0$ \\
\hline & $\mathrm{BCF}_{\mathrm{C}}$ & ND & $0.070 \pm 0.017$ (0.066) 0.049-0.11 \\
\hline & $\mathrm{BCF}_{\mathrm{S}}$ & ND & $0.083 \pm 0.035(0.081) 0.044-0.16$ \\
\hline \multirow[t]{6}{*}{$\mathrm{Cu}$} & Cap & $280 \pm 73(240) 210-440$ & $120 \pm 38$ (120) 60-210 \\
\hline & Stipe & $220 \pm 110(200) 120-590$ & $81 \pm 23$ (76) $37-130$ \\
\hline & $\mathrm{Q}_{\mathrm{C} / \mathrm{s}}$ & $1.4 \pm 0.4(1.5) 0.66-2.0$ & $1.6 \pm 0.3(1.6) 1.2-2.2$ \\
\hline & Soil & ND & $2.7 \pm 0.09$ (2.7) 2.6-2.8 \\
\hline & $\mathrm{BCF}_{\mathrm{C}}$ & ND & $46 \pm 15(45) 21-80$ \\
\hline & $\mathrm{BCF}_{\mathrm{s}}$ & ND & $30 \pm 9$ (28) $13-51$ \\
\hline
\end{tabular}


ANNEX 2. Continued.

\begin{tabular}{|c|c|c|c|}
\hline \multirow[t]{6}{*}{$\mathrm{Hg}$} & Cap & $5.3 \pm 0.8$ (5.3) 3.2-6.6 & $1.8 \pm 0.8$ (1.9) $0.05-2.8$ \\
\hline & Stipe & $3.2 \pm 0.9$ (3.1) 2.3-4.9 & $0.97 \pm 0.50$ (1.0) 0.05-2.0 \\
\hline & $\mathrm{Q}_{\mathrm{C} / \mathrm{S}}$ & $1.7 \pm 0.4(1.7) 1.2-2.4$ & $1.8 \pm 0.4(1.9) 1.0-2.6$ \\
\hline & Soil & $0.067 \pm 0.068(0.053) 0.017-0.27$ & $0.10 \pm 0.00(0.10) 0.095-0.10$ \\
\hline & $\mathrm{BCF}_{\mathrm{C}}$ & $160 \pm 100(180) 33-390$ & $18 \pm 8(19) 0.52-29$ \\
\hline & $\mathrm{BCF}_{\mathrm{S}}$ & $100 \pm 77(99) 19-290$ & $10 \pm 5(11) 0.52-21$ \\
\hline \multirow[t]{6}{*}{$\mathrm{Mn}$} & Cap & $22 \pm 9(20) 8.1-47$ & $21 \pm 8(20) 13-41$ \\
\hline & Stipe & $42 \pm 24(33) 12-92$ & $35 \pm 24(23) 11-84$ \\
\hline & $\mathrm{Q}_{\mathrm{C} / \mathrm{S}}$ & $0.65 \pm 0.33(0.63) 0.14-1.3$ & $0.88 \pm 0.54(0.86) 0.23-2.2$ \\
\hline & Soil & ND & $670 \pm 59(650) 620-750$ \\
\hline & $\mathrm{BCF}_{\mathrm{C}}$ & $\mathrm{ND}$ & $0.032 \pm 0.011(0.029) 0.021-0.061$ \\
\hline & $\mathrm{BCF}_{\mathrm{S}}$ & $\mathrm{ND}$ & $0.052 \pm 0.037(0.031) 0.018-0.13$ \\
\hline \multirow[t]{6}{*}{$\mathrm{Pb}$} & Cap & $4.7 \pm 3.0(4.0) 0.64-11$ & $1.7 \pm 0.6(1.5) 0.58-2.6$ \\
\hline & Stipe & $7.3 \pm 6.6(5.7) 1.4-27$ & $0.75 \pm 0.40(0.61) 0.37-1.7$ \\
\hline & $\mathrm{Q}_{\mathrm{C} / \mathrm{s}}$ & $1.2 \pm 1.8(0.54) 0.15-6.3$ & $2.4 \pm 1.2(2.2) 1.3-6.0$ \\
\hline & Soil & $\mathrm{ND}$ & $14 \pm 0(14) 14-14$ \\
\hline & $\mathrm{BCF}_{\mathrm{C}}$ & ND & $0.12 \pm 0.05(0.19) 0.041-0.18$ \\
\hline & $\mathrm{BCF}_{\mathrm{s}}$ & ND & $0.053 \pm 0.028(0.044) 0.027-0,12$ \\
\hline \multirow[t]{6}{*}{$\mathrm{Rb}$} & Cap & ND & $22 \pm 12(17) 9.4-42$ \\
\hline & Stipe & ND & $13 \pm 7(11) 5.6-26$ \\
\hline & $\mathrm{Q}_{\mathrm{C} / \mathrm{s}}$ & ND & $1.7 \pm 0.4(1.6) 1.4-2.7$ \\
\hline & Soil & ND & $1.4 \pm 0.4(1.4) 1.4-1.5$ \\
\hline & $\mathrm{BCF}_{\mathrm{C}}$ & ND & $16 \pm 8(12) 6.4-30$ \\
\hline & $\mathrm{BCF}_{\mathrm{s}}$ & ND & $9.0 \pm 4.2(7.8) 3.8-19$ \\
\hline \multirow[t]{6}{*}{$\mathrm{Sr}$} & Cap & ND & $0.40 \pm 0.17(0.35) 0.18-2.5$ \\
\hline & Stipe & $\mathrm{ND}$ & $0.46 \pm 0.23(0.36) 0.20-0.86$ \\
\hline & $\mathrm{Q}_{\mathrm{C} / \mathrm{s}}$ & ND & $0.99 \pm 0.45(0.91) 0.35-1.9$ \\
\hline & Soil & ND & $6.2 \pm 0.1(6.2) 6.1-6.3$ \\
\hline & $\mathrm{BCF}_{\mathrm{C}}$ & ND & $0.064 \pm 0.028(0.057) 0.030-0.12$ \\
\hline & $\mathrm{BCF}_{\mathrm{s}}$ & ND & $0.074 \pm 0.038(0.058) 0.049-0.11$ \\
\hline \multirow[t]{6}{*}{$\mathrm{Zn}$} & Cap & $96 \pm 23(90) 67-140$ & $110 \pm 10(110) 85-130$ \\
\hline & Stipe & $77 \pm 51(60) 35-210$ & $74 \pm 15(75) 52-97$ \\
\hline & $\mathrm{Q}_{\mathrm{C} / \mathrm{s}}$ & $1.5 \pm 0.5(1.7) 0.62-2.2$ & $1.5 \pm 0.2$ (1.6) $1.2-1.7$ \\
\hline & Soil & ND & $19 \pm 0(19) 19-20$ \\
\hline & $\mathrm{BCF}_{\mathrm{C}}$ & ND & $5.7 \pm 0.8(6.1) 4.3-7.1$ \\
\hline & $\mathrm{BCF}_{\mathrm{S}}$ & ND & $3.9 \pm 0.8(4.0) 2.6-6.1$ \\
\hline
\end{tabular}

${ }^{a}$ Not determined

${ }^{\mathrm{b}} \mathrm{Q}_{\mathrm{c} / \mathrm{s}}$ values of the quotient of metal contents in cap to stipe 
Nickel was determined only in mushrooms and soils from the Lubraniec and Poniatowa sites. The soil Ni contents were similar ( $p>0.05$ ) for the two spatially distant sites. Caps contained $\mathrm{Ni}$ in content varying between $0.29 \pm 0.47$ and $0.86 \pm 0.22$ (range 0.01-1.5) $\mathrm{mg} \mathrm{kg}^{-1} \mathrm{dm}$, while the stipes were a little more abundant in $\mathrm{Ni}$ than the caps $(p<0.05$; Mann-Whitney $U$ test). From the data summarized in Annex 1 it can be concluded that the $M$. procera bioexcludes Ni. Laboratory studies showed that $\mathrm{Ni}$ (from $\mathrm{NiCl}_{2}$ ) was absorbed by mycelium and accumulated by $M$. procera, but the mushroom growth was impaired as the Ni content increased in the substrate medium from 0.05 to $0.8 \mathrm{mM}$ [53]. Rubidium is effectively bioconcentrated by $M$. procera in caps (BCF $\sim 100)$ and stipes (BCF 40). Rubidium contents in the soil were approximately 0.40 $\mathrm{mg} \mathrm{kg}^{-1} \mathrm{dm}$, while the mean content in the caps was $38 \pm 7$ (range 27-53) $\mathrm{mg} \mathrm{Rb} \mathrm{kg}^{-1} \mathrm{dm}$ (Annex 1).

\section{Toxic Metals $(\mathrm{Cd}, \mathrm{Pb}, \mathrm{Hg}, \mathrm{Ag})$}

These metals $(\mathrm{Cd}, \mathrm{Pb}, \mathrm{Hg}$, and $\mathrm{Ag})$ are highly toxic to mammals. In the caps of $M$. procera from the Lubraniec and Poniatowa sites, the mean $\mathrm{Pb}$ content varied from $1.7 \pm 0.6$ to $5.9 \pm 1.7$ (range $0.58-11$ ) $\mathrm{mg} \mathrm{kg}^{-1} \mathrm{dm}$. The mean $\mathrm{Hg}$ contents in caps from the Lubraniec, Poniatowa, Jarocin, and Gubin sites are $2.1 \pm 0.6,3.1 \pm 0.9$ (range 1.3-4.6), $1.8 \pm 0.8$, and $5.3 \pm 0.8 \mathrm{mg} \mathrm{kg}^{-1} \mathrm{dm}$, respectively (Annex 1). Silver content in caps (for three sites including the Jarocin site) varied from $1.2 \pm 0.7$ to $16 \pm 7$ (range 0.40 31) $\mathrm{mg} \mathrm{kg}^{-1} \mathrm{dm}$, and for $\mathrm{Cd}$ (for six sites) the mean values varied from $0.56 \pm 0.13$ to $4.9 \pm 5.4$ (range $0.07-17$ ) $\mathrm{mg} \mathrm{kg}^{-1}$ $\mathrm{dm}$ (Annex 1 and 2). The abundance of these metals in the caps varied significantly $(0.01<\mathrm{p}<0.05$; Mann-Whitney $U$ test) for some of the sites.

Cadmium, mercury, and silver were accumulated by M. procera while $\mathrm{Pb}$ was bioexcluded. The ranges of $\mathrm{Cd}$, $\mathrm{Ag}, \mathrm{Hg}$, and $\mathrm{Pb}$ contents in the soils were 0.1-0.4, 0.01$0.06,0.05-0.15$, and $8-15 \mathrm{mg} \mathrm{kg}^{-1} \mathrm{dm}$, respectively, while the range of their BCF values for caps were 4-15, 20-470, 15-160, and 0.2-0.7 (for $\mathrm{Cd}, \mathrm{Ag}, \mathrm{Hg}$, and $\mathrm{Pb}$ ), respectively (Annexes 1 and 2). For some of the sampled sites, Ag and $\mathrm{Hg}$ were highly bioconcentrated by $M$. procera and their BCF values reached more than 100. Earlier studies reported that $M$. procera has the ability to efficiently bioconcentrate $\mathrm{Hg}$ [54-57]. This species, apart from being rich in the essential elements (including $\mathrm{Cu}$ and $\mathrm{Zn}$ ), is also rich in $\mathrm{Cd}, \mathrm{Pb}, \mathrm{Hg}$, and $\mathrm{Ag}$ [2, 14, 26, 40, 56].

The occurrence of essential and toxic trace elements in edible mushrooms collected in the wild as well as their intake rates, nutritional benefits, and likely risks, are of primarily concern to consumers. The traditional cooking recipes describe that caps of freshly collected $M$. procera are especially good for stuffing (filling) and then broiling, or for frying in a pan with some oil or butter after being dipped in whisked egg and breadcrumbs. In Slovakia, for example, baked $M$. procera caps are stuffed with ground pork, oregano, and garlic. In these culinary treatments the possible leaching of the mineral contents of the mushroom cap is small, if any, and can therefore be ignored when estimating toxic metals intake rates and the likely risks to consumers.

\section{Mercury}

For the assessment of possible risks due to intake of $\mathrm{Hg}$ accumulated in caps of $M$. procera, the reference dose (RfD; $0.0003 \mathrm{mg} \mathrm{kg}{ }^{-1}$ body mass daily) and established value of provisionally tolerable weekly intake (PTWI; $0.004 \mathrm{mg} \mathrm{kg}^{-1} \mathrm{bm}$ ) were applied [58-59]. From a toxicological point of view, $\mathrm{Hg}$ content of caps of $M$. procera is of concern. A meal cooked using 300 or $500 \mathrm{~g}$ of caps collected at the Jarocin, Lubraniec, Poniatowa, or Gubin sites will result in the intake of $\mathrm{Hg}$ ranging from 0.9 to 2.7 or 1.5 to $4.4 \mu \mathrm{g} \mathrm{kg}^{-1}$ body mass for consumption of $300 \mathrm{~g}$ or $500 \mathrm{~g}$ of caps, respectively. These doses were derived from the minimum and maximum median values of 0.18 (Jarocin) and 0.53 (Gubin) $\mathrm{mg} \mathrm{Hg} \mathrm{kg} \mathrm{kaps}^{-1}$, wet weight (assuming 90\% water content in caps and an adult individual of $60 \mathrm{~kg}$ body mass). The weekly consumption of $500 \mathrm{~g}$ of caps of $M$. procera from Gubin, which showed the highest $\mathrm{Hg}$ content, will result in the intake of $0.26 \mathrm{mg} \mathrm{Hg}$, which is above the $0.24 \mathrm{Hg}$ recommended dose of PTWI (assuming that no $\mathrm{Hg}$ from other foods is ingested).

Selenium plays a protective role against $\mathrm{Hg}$ contained in foods. It is presumed that the co-occurrence of Se and methyl mercury or total $\mathrm{Hg}$ in stoichiometric ratio could prevent the toxic effects of $\mathrm{Hg}$ [60]. Among fungi $M$. procera is relatively rich in Se. As reviewed recently, Se content of the caps of $M$. procera usually varies around $5 \mathrm{mg} \mathrm{kg}^{-1} \mathrm{dm}$ [61]. In a recent study, the average Se content of $M$. procera $(\mathrm{n}=11)$ collected from Spain were $16 \pm 9 \mathrm{mg} \mathrm{kg}^{-1} \mathrm{dm}$ for the hymenophores and $5.5 \pm 2.3 \mathrm{mg} \mathrm{kg}^{-1} \mathrm{dm}$ for the rest of the fruiting body (including inedible stipes) [39].

The PTWI for methylmercury is $0.0016 \mathrm{mg} \mathrm{kg}^{-1}$ body mass [62]. The methylmercury content of $M$. procera were not determined in this study. Bargagli and Baldi reported $0.06 \%$ of the total mercury content parasol mushroom as methyl $\mathrm{Hg}$ in a single specimen of Parasol Mushroom from a cinnabar mining area near Siena, Italy (4 mg Hg kg-1 dm) [63].

\section{Cadmium}

Cadmium is known for its high toxicity to the mammalian body systems and especially because of its nephrotoxicity and accumulation in kidneys. The PTWI of $7 \mu \mathrm{g} \mathrm{Cd} \mathrm{kg}^{-1}$ body mass (equivalent to $1 \mu \mathrm{g} \mathrm{kg}^{-1} \mathrm{bm}$ daily) was set earlier by the World Health Organization [64]. The provisional tolerable monthly intake (PTMI) for this metal is $25 \mu \mathrm{g} \mathrm{kg}^{-1} \mathrm{bm}$ [65]. The median values of $\mathrm{Cd}$ in caps from six of the sites surveyed varied from 0.57 (Lubraniec) to 2.2 (Gubin) $\mathrm{mg} \mathrm{kg}^{-1} \mathrm{dm}$ (0.057 and $0.22 \mathrm{mg} \mathrm{kg}^{-1}$ fresh weight; assuming $90 \%$ water content). In the European Union the maximum level of cadmium allowed for mushrooms is $1.0 \mathrm{mg} \mathrm{kg}^{-1}$ fresh product (10 $\mathrm{mg} \mathrm{kg}^{-1} \mathrm{dm}$; assuming 90\% moisture content) [66]. The 
median and arithmetic mean content values in this study were below the acceptable limit, and only a few specimens collected from Gostyńsko-Włocławskie Forest and from the Gubin region contained $\mathrm{Cd}$ in caps at levels $>10 \mathrm{mg} \mathrm{kg}^{-1} \mathrm{dm}$ (Table 1, Annex 1).

A meal made with 300 or $500 \mathrm{~g}$ of caps of M. procera from these sites will result in $\mathrm{Cd}$ intake of between 17 and 28 or 66 and $110 \mu \mathrm{g} \mathrm{Cd}$, respectively, assuming no $\mathrm{Cd}$ intake from other foods is ingested. These amounts correspond to doses of 0.28 to 0.47 (for consumption of $300 \mathrm{~g}$ of caps of $M$. procera or 1.1 to $1.8 \mu \mathrm{g} \mathrm{Cd} \mathrm{kg}{ }^{-1}$ $\mathrm{bm}$ (for consumption of $500 \mathrm{~g}$ of caps). These estimated values show that a tolerable weekly intake (TWI) dose of $150 \mu \mathrm{g} \mathrm{Cd}$ (for an individual of $60 \mathrm{~kg} \mathrm{bm}$ ) will not be exceeded when eating a large meal $(500 \mathrm{~g})$ made of caps of $M$. procera collected from the Gubin region once weekly, or two to three meals weekly for caps from the other investigated sites. The estimated TWI value of $150 \mu \mathrm{g}$ for $\mathrm{Cd}$ is equivalent to $21 \mu \mathrm{g}$ daily intake and this value is close to the estimated $\mathrm{Cd}$ intake from a $300 \mathrm{~g}$ portion of fresh caps of parasol mushrooms from the other sites surveyed.

The caps of some $M$. procera samples from four of the six sites surveyed showed substantially higher $\mathrm{Cd}$ contents (Annex 1 and 2) compared to the maximum median values used in these estimations. This suggests that consumers could be exposed to relatively higher doses of $\mathrm{Cd}$ if they consume larger meals of $M$. procera often - especially during the mushrooming season each year.

\section{Lead}

The median $\mathrm{Pb}$ values of caps from four of the sites surveyed were 1.5 (Jarocin), 2.2 (Lubraniec), 4.0 (Gubin), and 5.2 (Poniatowa) $\mathrm{mg} \mathrm{kg}^{-1} \mathrm{dm}$ (between 0.15 and $0.52 \mathrm{mg} \mathrm{kg}{ }^{-1}$ fresh product; assuming 90\% moisture content). In the EU regulation, the permitted content of $\mathrm{Pb}$ in cultivated mushrooms (champignon, oyster, and shiitake) is $0.3 \mathrm{mg} \mathrm{kg}^{-1}$ fresh mushrooms $\left(3.0 \mathrm{mg} \mathrm{kg}^{-1} \mathrm{dm}\right.$; assuming 90\% moisture) [67]. For M. procera specimens from the Poniatowa and Gubin sites, the median $\mathrm{Pb}$ contents for caps exceeded the EU limit (also for some specimens from the Lubraniec site) (Annexes 1 and 2). A meal made with 300 or $500 \mathrm{~g}$ of caps from these sites will result in the intake of between 45 and 75 or 156 and $260 \mu \mathrm{g} \mathrm{Pb}$, respectively. These values correspond to doses of 0.75 to 1.2 or 2.6 to $4.3 \mu \mathrm{g} \mathrm{Pb} \mathrm{kg} \mathrm{Pb}^{-1} \mathrm{bm}$, assuming no $\mathrm{Pb}$ intake from other foods.

The FAO/WHO JECFA established a PTWI for lead of $1.5 \mathrm{mg}$ for person of $60 \mathrm{~kg}$ body mass, which is equivalent to $214 \mu \mathrm{g}$ daily, $25 \mu \mathrm{g} \mathrm{kg}^{-1} \mathrm{bm}$ weekly, or $3.6 \mu \mathrm{g} \mathrm{kg-}^{1} \mathrm{bm}$ daily [68]. Nevertheless, because of the relatively elevated $\mathrm{Pb}$ levels accumulated in $M$. procera, the frequent eating of caps during the mushrooming season can result in intake doses close to or exceeding the allowed intake value. This can be of special toxicological concern since a significant proportion of the caps in specimens studied showed $\mathrm{Pb}$ content exceeding the median values determined (Tables 1 and 2).
Table 2. Eigenvalues of correlation matrix and related statistics ${ }^{\mathrm{a}}$

\begin{tabular}{|c|c|c|c|c|}
\hline Factor & Eigenvalue & $\begin{array}{c}\text { Percent } \\
\text { of total } \\
\text { variance }\end{array}$ & $\begin{array}{c}\text { Cumulative } \\
\text { eigenvalue }\end{array}$ & $\begin{array}{c}\text { Cumulative } \\
\text { percent }\end{array}$ \\
\hline 1 & 9.20 & 76.65 & 9.20 & 76.65 \\
\hline 2 & 1.75 & 14.56 & 10.95 & 91.25 \\
\hline
\end{tabular}

${ }^{\text {a }}$ Minimum Eigenvalue $=1$

\section{Silver}

Unlike $\mathrm{Hg}, \mathrm{Cd}$, or $\mathrm{Pb}$, there are no intake limits or tolerance values set for Ag in foodstuffs. Silver ion is very reactive and quickly bonds to the surface of epithelium cells of the alimentary tract and hence is largely excreted (not absorbed) [69], thereby raising questions about the absorption rates of $\mathrm{Ag}$ from the food chain — especially for Ag in edible wild mushrooms.

Many mushroom species are relatively rich in silver, and this metal is efficiently taken-up from contaminated substratum by the champignon mushroom (Agaricus bisporus) or in the wild by the meadow mushroom (A. campestris), while the warted amanita (Amanita strobiliformis) is a hyperacumulator of silver [11, 24-26]. Plant foods such as cereals, vegetables, pulses, and fruits are known to contain much lower Ag when compared to many mushroom species. The chemical species of Ag in mushrooms were identified recently as the metallothionein isoforms involved in intracellular sequestration of $\mathrm{Ag}$ by A. strobiliformis [24]. The availability and toxicity of $\mathrm{Ag}$ bonded to fungal peptides from a mushroom meal is unknown.

The median values of silver in caps at three of the sites surveyed varied widely: 1.2 for Jarocin, 3.2 for Lubraniec, and 13 for Poniatowa $\mathrm{mg} \mathrm{kg}^{-1} \mathrm{dm}$ (range 0.12 to $1.3 \mathrm{mg}$ $\mathrm{kg}^{-1}$ fresh productt; assuming $90 \%$ water content). Hence, a meal made with 300 or $500 \mathrm{~g}$ of fresh caps of M. procera collected from these sites (Jarocin, Lubraniec, and Poniatowa) will result in intake of silver of between 36 and 60 or 390 and $650 \mu \mathrm{g} \mathrm{Ag}$, respectively, assuming no silver intake from other foods is ingested. These amounts correspond to doses of 0.6 to 1 or 6.5 to $10.8 \mu \mathrm{g} \mathrm{Ag} \mathrm{kg}^{-1}$ bm.

\section{Principal Component Analysis}

In order to examine the profiles of metals sequestered in the caps from four sites (Table 1), the principal component analysis (PCA) was used. The contents of $\mathrm{K}, \mathrm{Mg}, \mathrm{Al}, \mathrm{Ba}$, $\mathrm{Ca}, \mathrm{Cd}, \mathrm{Cu}, \mathrm{Fe}, \mathrm{Mn}, \mathrm{Na}, \mathrm{Sr}$, and $\mathrm{Zn}$ were used as variables. The correlation matrixes resulting from the PCA are displayed in Tables 2 and 3. The number of components was chosen with the ordinary rule of selecting eigenvalues $>1$. The PCA of the data matrix gave a two-dimensional model that explained $91 \%$ ( $77 \%$ and $15 \%$, respectively) of the total variance in the data set. The loading plot (Fig. 2) shows that the first principal component 
Table 3. The values of the coefficients of principal components (factor loadings) ${ }^{\mathrm{a}}$

\begin{tabular}{|c|c|c|}
\hline Metal & Factor 1 & Factor 2 \\
\hline $\mathrm{K}$ & $\mathbf{- 0 . 9 9 3 0}$ & -0.0569 \\
\hline $\mathrm{Mg}$ & $\mathbf{- 0 . 9 6 4 1}$ & -0.1692 \\
\hline $\mathrm{Al}$ & $\mathbf{- 0 . 9 1 1 7}$ & 0.3204 \\
\hline $\mathrm{Ba}$ & $\mathbf{- 0 . 9 8 9 6}$ & -0.0055 \\
\hline $\mathrm{Ca}$ & $\mathbf{- 0 . 9 8 9 9}$ & 0.1298 \\
\hline $\mathrm{Cd}$ & $\mathbf{- 0 . 3 8 6 1}$ & $\mathbf{- 0 . 7 8 7 5}$ \\
\hline $\mathrm{Cu}$ & $\mathbf{- 0 . 9 1 7 7}$ & -0.3143 \\
\hline $\mathrm{Fe}$ & $\mathbf{- 0 . 8 8 1 8}$ & -0.3769 \\
\hline $\mathrm{Mn}$ & $\mathbf{- 0 . 7 1 3 1}$ & 0.2808 \\
\hline $\mathrm{Na}$ & 0.5587 & $\mathbf{- 0 . 8 0 6 2}$ \\
\hline $\mathrm{Sr}$ & $\mathbf{- 0 . 9 3 1 9}$ & 0.0775 \\
\hline $\mathrm{Zn}$ & -0.9983 & 0.0049 \\
\hline
\end{tabular}

${ }^{\text {a }}$ Number of factors $=6$; factor loadings $>\mathbf{0 . 7}$

(eigenvalue $=9.2$ ) is influenced by negatively correlated variables such as $\mathrm{K}, \mathrm{Mg}, \mathrm{Al}, \mathrm{Ba}, \mathrm{Ca}, \mathrm{Cu}, \mathrm{Fe}, \mathrm{Mn}, \mathrm{Sr}$, and $\mathrm{Zn}$. The second factor (eigenvalue $=1.75$ ) presented a negative correlation with $\mathrm{Cd}$ (coefficient -0.79 ) and $\mathrm{Na}$ (coefficient -0.81).

In the two-dimensional factor space spanned by vectors $\mathrm{PC} 1$ and $\mathrm{PC} 2, \mathrm{~K}, \mathrm{Ba}, \mathrm{Ca}$, and $\mathrm{Zn}$ are the least correlated to $\mathrm{PC} 1$ (coef. -0.99). Cadmium and sodium are negatively correlated to $\mathrm{PC} 1$ and $\mathrm{PC} 2$, respectively. The loading plot (Fig. 2) shows graphically the association existing among metals in the factor matrices. Other metals are not apparently associated with a definite-factor axis.

A projection of $M$. procera trace metals data set on the PC plane allows us to visualize the contribution of the particular groups of metallic elements to the specimens' spread (Fig. 3). First, the principal component showed a strong separation of Poniatowa site from Lubraniec site, Starachowickie Forest, and Gostyńsko-Włocławskie Forest, which clustered close together with respect to $\mathrm{PC} 1$. Metals such as $\mathrm{K}, \mathrm{Mg}, \mathrm{Al}, \mathrm{Ba}, \mathrm{Ca}, \mathrm{Cu}, \mathrm{Sr}$, and $\mathrm{Zn}$ introduced the greatest variance in the mineral constituents' composition, while only caps collected at the Poniatowa site could be separated based on these criteria (Fig. 3). PC2 indicated that the caps collected from GostyńskoWłocławskie Forest are low in $\mathrm{Cd}$ and $\mathrm{Na}$ contents (Fig. $3)$. This configuration of cluster inter-correlations could be explained by considering that the contents of macro and trace metals in higher mushrooms depends mainly on several factors, including biological ones (which are to some degree species- or genera-dependent), as well as the soil bedrock and other environmental factors [46-48, 70].

In order to demonstrate possible spatial variations in $M$. procera mineral composition, the we conducted a cluster analysis (CA) based on the cap and soil data set (Fig. 4). The CA diagram divided all cases into two main fractions, and this apparently reflected interdependent relationships occurring between them. The first fraction separated caps of $M$. procera collected from four stands in south-central Poland while the second fraction separated soil collected from the same sites. In the first cluster the strongest similarity occurred between caps collected from the Lubraniec site and Starachowickie Forest. In the second case, up to two subclusters could be recognized related to soils from Gostyńsko-Włocławskie Forest and the Poniatowa site.

\section{Conclusions}

M. procera from wild forest sites are efficient absorbers and accumulators of certain metals $(\mathrm{Cd}, \mathrm{Cu}, \mathrm{K}, \mathrm{Mg}, \mathrm{Na}$, $\mathrm{Zn}$ ) that naturally occur in the substrates on which the mushroom mycelium develop. Though delicious and rich in many minerals, when cooked the caps of $M$. procera can provide to the consumer/fanciers substantial quantities of several essential trace elements but also such toxic metals as cadmium, lead, and mercury. Considering the contents of cadmium, lead, and mercury observed in the caps (which varied spatially) and the recommended intake limits for these toxic metals, the frequency of eating $M$. procera by people fond of this species (or people with easy access to it during the mushrooming season) should be limited to one or two meals weekly. The frequent eating of $M$. procera collected from unpolluted forests within the investigated sites while providing the unique taste of a juicy dish will not expose consumers to doses of cadmium, lead, and mercury above recommended limits.

\section{Acknowledgements}

This study was in part financially supported to by the National Science Centre of Poland under PRELUDIUM (Project No. DEC-2011/03/N/NZ9/04136). Technical support from Joanna Gozdek, Magdalena Fechner, Magdalena Kręcicka, and Ewelina Pilarczyk is acknowledged.

\section{References}

1. BOROVIČKA J., ̌̌ANDA Z. Distribution of iron, zinc and selenium in macrofungi. Mycol. Prog. 6, 249, 2007.

2. GARCIÁ M.Á., ALONSO J., MELGAR M.J. Lead in edible mushrooms. Levels and bioconcentration factors. J. Hazard. Mat. 167, 777, 2009.

3. LIU H., ZHANG J., LI T., SHI Y., WANG Y. Mineral element levels in wild edible mushrooms from Yunnan, China“. Biol. Trace. Elem. Res. 147, 341, 2012.

4. MAZURKIEWICZ N., PODLASIŃSKA J. Bioaccumulation of trace elements in wild-growing edible mushrooms from Lubuskie voivodeship, Poland. J. Chem. Ecol. 30, 110, 2014.

5. TEL G., ÇAVDAR H., DEVECI E., ÖZTÜRK M., DURU M.E., TURKOĞLU A. Minerals and metals in mushroom species in Anatolia. Food Addit. Contam. B. 7, 226, 2014.

6. FALANDYSZ J., DREWNOWSKA M. Macro and trace elements in Common Chanterelle (Cantharellus cibarius) 
mushroom from the European background areas in Poland: Composition, accumulation, dietary exposure and data review for species. J. Environ. Sci. Heal. B. 50, 374, 2015.

7. SARIKURKCU C., TEPE B., KOCAK M.S., UREN M.C. Metal concentration and antioxidant activity of edible mushrooms from Turkey. Food Chem. 175, 549, 2015.

8. ZHANG D., FRANKOWSKA A., JARZYŃSKA G., KOJTA A.K., DREWNOWSKA M., WYDMAŃSKA D., BIELAWSKI L., WANG J., FALANDYSZ J. Metals of King Bolete (Boletus edulis) collected at the same site over two years. Afr. J. Agric. Res. 5, 3050, 2010.

9. JOURNAL OF LAWS OF THE REPUBLIC OF POLAND Dz.U.11.115.672, regulation, Ministry of Health on 17 May 2011. on mushrooms authorized for the marketing or production of mushroom products, resources foodstuffs containing mushrooms and also mushroom classifier and mushroom expert. Annexes 1 to Regulation of the Minister of Health of 17 May 2011. The list of mushrooms authorized for marketing or production mushroom products and foodstuffs containing mushrooms.

10. http://www2.mz.gov.pl/wwwmz/slajd? $\mathrm{mr}=\mathrm{m} 4 \& \mathrm{~ms}=1 \& \mathrm{ml}=$ $\mathrm{p} 1 \& \mathrm{mi}=5 \& \mathrm{mx}=0 \& \mathrm{mt}=\& \mathrm{my}=9 \& \mathrm{ma}=017636(27.04 .2016 \mathrm{r}$. $)$

11. GUS, Forestry, Central Statistical Office, Warsaw, 2014. http://stat.gov.pl/en/topics/agriculture-forestry/forestry/ forestry-2014,1,5.html (27.04.2015r.)

12. BOROVIČKA J., KOTRBA P., GRYNDLER M., MIHALJEIČ M., ŘANDA Z., ROHOVEC J., CAJTHAML T., STIJVE T., DUNN C.E. Bioaccumulation of silver in ectomycorrhizal and saprobic macrofungi from pristine and polluted areas. Sci. Total. Environ. 408, 2733, 2010.

13. FALANDYSZ J., KUNITO T., KUBOTA R., LIPKA K., MAZUR A., FALANDYSZ J.J., TANABE S. Selected elements in Fly Agaric Amanita muscaria. J. Environ. Sci. Heal. A. 42, 1615, 2007.

14. FALANDYSZ J., KUNITO T., KUBOTA R., BIELAWSKI L., FRANKOWSKA A., FALANDYSZ J.J., TANABE S. Multivariate characterization of elements accumulated in King Bolete Boletus edulis mushroom at lowland and high mountain regions. J. Environ. Sci. Heal. A. 43, 1692, 2008.

15. FALANDYSZ J., KUNITO T., KUBOTA R., GUCIA M., MAZUR A., FALANDYSZ J.J., TANABE S. Some mineral constituents of Parasol Mushroom Macrolepiota procera. J. Environ. Sci. Heal. B. 43, 187, 2008.

16. ISILDAK O., TÜRKEKUL I., ELMSTAŞ M., ABOULENEIN H. Bioaccumulation of heavy metals in some wildgrown edible mushrooms. Anal. Lett. 40, 1099, 2007.

17. LI T., WANG Y.Z., ZHANG J., ZHAO Y.L., LIU H. Trace element content of Boletus tomentipes mushroom collected from Yunnan, China. Food Chem. 127, 1828, 2011.

18. FALANDYSZ J., BOROVIČKA J. Macro and trace mineral constituents and radionuclides in mushrooms - health benefits and risks. Appl. Microbiol. Biot. 97, 477, 2013.

19. FALANDYSZ J., ZALEWSKA T., KRASIŃSKA G., APANEL A., WANG Y., PANKAVEC S. Evaluation of the radioactive contamination in Fungi genus Boletus in the region of Europe and Yunnan Province in China. App. Microbiol. Biot. 99, 8217, 2015.

20. SANIEWSKI M., ZALEWSKA T., KRASIŃSKA G., SZYLKE N., WANG Y., FALANDYSZ J. ${ }^{90} \mathrm{Sr}$ in King Bolete Boletus edulis and certain other mushrooms consumed in Europe and China. Sci. Total Environ. 543, 287, 2016.

21. DA SILVA J.A.L., FRAÚSTO DA SILVA J.J.R., POMBEIRO A.J.L. Amavadin, a vanadium natural complex: Its role and applications. Coordin. Chem. Rev. 257, 2388, 2013.
22. STIJVE T., VELLINGA E.C., HERRMANN A. Arsenic accumulation in some higher fungi. Persoonia. 14, 161, 1990.

23. ZHANG J., LI T., YANG Y., LIU H., WANG W. Arsenic concentrations and associated health risks in Laccaria mushrooms from Yunnan (SW China). Biol. Trace. Elem. Res. 164, 261, 2015.

24. STIJVE T., NOORLOOS T., BYRNE A.R., ŠLEJKOVEC Z., GOESSLER W. High selenium levels in edible Albatrellus mushroom. Deut. Lebensm.-Rundsch. 94, 275, 1998.

25. BOROVIČKA J., ŘANDA Z., JELÍNEK E., KOTRBA P., DUNN C.E. Hyperaccumulation of silver by Amanita strobiliformis and related species of the section Lepidella. Mycol. Res. 111, 1339, 2007.

26. FALANDYSZ J., DANISIEWICZ D. Bioconcentration factors (BCF) of silver in wild Agaricus campestris. B. Environ. Contam. Tox. 55, 122, 1995.

27. FALANDYSZ J., BONA H., DANISIEWICZ D. Silver content of wild-grown mushrooms from northern Poland. Z. Lebensm. Unters. For. 199, 222, 1994.

28. FALANDYSZ J., BONA H., DANISIEWICZ D. Silver uptake by Agaricus bisporus from an artificially enriched substrate. Z. Lebensm. Unters. For. 199, 225, 1994.

29. KOJTA A.K., JARZYŃSKA G., FALANDYSZ J. Mineral composition and heavy metals accumulation capacity of Bay Bolete's (Xerocomus badius) fruiting bodies collected near a former gold and copper mining area. J. Geochem. Explor. 121, 76, 2012.

30. OSOBOVÁ M., URBAN V., JEDELSKÝ P.L., BOROVIČKA J., GRYNDLER M., RUM T., KOTRBA P. Three metallothionein isoforms and sequestration of intracellular silver in the hyperaccumulator Amanita strobiliformis. New. Phytol. 190, 916, 2011.

31. ALONSO J., SALGADO M.J., GARCIÁ M.Á, MELGAR M.J. Accumulation of mercury in edible macrofungi: Influence of some factors. Arch. Environ. Con. Tox. 44, 158, 2000.

32. CHOJNACKA A., JARZYŃSKA G., DREWNOWSKA M., NNOROM I.C., FALANDYSZ J. Mercury in Yellowcracking Boletes Xerocomus subtomentosus mushrooms and soils from spatially diverse sites: Assessment of bioconcentration potential by species and human intake. J. Environ. Sci. Heal. A. 47, 2094, 2012.

33. FALANDYSZ J., GUCIA M., FRANKOWSKAA., KAWANO M., SKWARZEC B. Total mercury in wild mushrooms and underlying soil substrate from the city of Umeå and its surroundings, Sweden. B. Environ. Contam. Tox. 67, 763, 2001.

34. FALANDYSZ J., BIELAWSKI L., KANNAN K., GUCIA M., LIPKA K., BRZOSTOWSKI A. Mercury in wild mushrooms and underlying soil substrate from the great lakes land in Poland. J. Environ. Monitor. 4, 473, 2002.

35. FALANDYSZ J., GUCIA M., BRZOSTOWSKI A., KAWANO M., BIELAWSKI L., FRANKOWSKA A., WYRZYKOWSKA B. Content and bioconcentration of mercury in mushrooms from northern Poland. Food. Addit. Contam. 20, 247, 2003.

36. FALANDYSZ J., KOJTA A.K., JARZYŃSKA G., DREWNOWSKA M., DRYŻAŁOWSKA A., WYDMAŃSKA D., KOWALEWSKA I., WACKO A., SZLOSOWSKA M., KANNAN K., SZEFER P. Mercury in Bay Bolete Xerocomus badius: bioconcentration by fungus and assessment of element intake by humans eating fruiting bodies. Food. Addit. Contam. A. 29, 951, 2012.

37. FALANDYSZ J., KOWALEWSKA I., NNOROM I.C., DREWNOWSKA M., JARZYŃSKA G. Mercury in Red Aspen Boletes (Leccinum aurantiacum) mushrooms and the soils. J. Environ. Sci. Heal. A. 47, 1695, 2012. 
38. FALANDYSZ J., WIDZICKA E., KOJTA A.K., JARZYŃSKA G., DREWNOWSKA M., DANISIEWICZCZUPRYŃSKA D., DRYŻAŁOWSKA A., LENZ E., NNOROM I.C. Mercury in Common Chanterelles mushrooms: Cantharellus spp. update. Food Chem. 133, 842, 2012.

39. FALANDYSZ J., KRASIŃSKA G., PANKAVEC S., NNOROM I.C. Mercury in certain Boletus mushrooms from Poland and Belarus. J. Environ. Sci. Heal. B. 49, 690, 2014.

40. MELGAR M.J., ALONSO J., GARCİA M.Á. Mercury in edible mushrooms and soil. Bioconcentration factors and toxicological risk. Sci. Total Environ. 407, 5328, 2009.

41. COCCHI L., VESCOVI L., PETRINI L., PETRINI O. Heavy metals in edible mushrooms in Italy. Food Chem. 98, 277, 2006.

42. NNOROM I.C., JARZYŃSKA G., FALANDYSZ J., DREWNOWSKA M., OKOYE I., OJI-NNOROM CH.G. Occurrence and accumulation of mercury in two species of wild grown Pleurotus mushrooms from Southeastern Nigeria. Ecotox. Environ. Safe. 84, 78, 2012.

43. RIEDER S.R., BRUNNER I., HORVAT M., JACOBS A., FREY B. Accumulation of mercury and methylmercury by mushrooms and earthworms from forest soils. Environ. Pollut. 159, 2861, 2011.

44. SVOBODA L., KALAČ P. Contamination of two edible Agaricus spp. mushrooms growing in a town with cadmium, lead, and mercury. B. Environ. Contam. Tox. 71, 123, 2003.

45. VETTER J., STILLER I. Ásványi anyagok mennyiségének alakulása a gomba terötestben (Macrolepiota procera). Mikolódiai Közlemények. 36, 33, 1977.

46. ZIMMERMANNOVA K., SVOBODA L., KALAČ P. Mercury, cadmium, lead and copper contents in fruiting bodies of selected edible mushrooms in contaminated Middle Spiš region. Ekologia (Bratislava). 20, 440, 2001.

47. ALOUPI M., KOUTROTSIOS G., KOULOUSARIS M., KALOGEROPOULOS N. Trace metal contents in wild edible mushrooms growing on serpentine and volcanic soils on the island of Lesvos, Greece. Ecotox. Environ. Safe. 78, 184, 2011.

48. FALANDYSZ J., DREWNOWSKA M., JARZYŃSKA G., ZHANG D., ZHANG Y., WANG J. Mineral constituents in Common Chanterelles and soils collected from a high mountain and lowland sites in Poland. J Mt Sci-Engl 9, 6975, 2012.

49. ŘANDA Z., KUČERA J. Trace elements in higher fungi (mushrooms) determined by activation analysis. J. Radioanal. Nucl. Ch. 259, 99, 2004.

50. BRZOSTOWSKI A., FALANDYSZ J., JARZYŃSKA G., ZHANG D. Bioconcentration potential of metallic elements by Poison Pax (Paxillus involutus) mushroom. J. Environ. Sci. Heal. A. 46, 378, 2011.

51. BRZOSTOWSKI A., JARZYŃSKA G., KOJTA A.K., WYDMAŃSKA D., FALANDYSZ J. Variations in metal levels accumulated in Poison Pax (Paxillus involutus) mushroom collected at one site over four years. J. Environ. Sci. Heal. A. 46, 581, 2011.

52. JARZYNSSKA G., FALANDYSZ J. The determination of mercury in mushrooms by CV-AAS and ICP-OES techniques. J. Environ. Sci. Heal. A. 46, 569, 2011.

53. MILES P.G., CHANG S.-T., Mushroom Biology: Concise Basics and Current Developments, World Scientific Publishing Company, Singapore, 1997.
54. BAPTISTA P., FERREIRA S., SOARES E., COELHO V., DE LOURDES BARTOS $\mathrm{M}$. Tolerance and stress response of Macrolepiota procera to nickel. J. Agr. Food. Chem. 57, 7145, 2009.

55. FALANDYSZ J., CHWIR A. The concentrations and bioconcentration factors of mercury in mushrooms from the Mierzeja Wiślana sand-bar, Northern Poland. Sci. Total. Environ. 203, 221, 1997.

56. FALANDYSZ J., GUCIA M., MAZUR A. Content and bioconcentration factors of mercury by Parasol Mushroom Macrolepiota procera. J. Environ. Sci. Heal. B. 42, 735, 2007.

57. GIANNACCINI G., BETTI L., PALEGO L., MASCIA G., SCHMID L., LANZA M., MELA A., FABBRINI L., BIONDI L., LUCACCHINI A. The trace element content of top-soil and wild edible mushroom samples collected in Tuscany, Italy. Environ. Monit. Assess. 184, 7579, 2012.

58. GUCIA M., JARZYŃSKA G., KOJTA A.K., FALANDYSZ J. Temporal variability in twenty chemical elements content of Parasol Mushroom (Macrolepiota procera) collected from two sites over a few years. J. Environ. Sci. Heal. B. 47, 81, 2012.

59. JECFA. Joint FAO/WHO Expert Committee on Food Additives. Seventy-second meeting. Rome, 16-25 February 2010. Summary and Conclusions. JECFA/72/SC. Food and Agriculture Organization of the United Nations World Health Organization; Issued $16^{\text {th }}$ March 2010.

60. EPA. Peer Workshop on Mercury Issues. Summary Report. Environmental Criteria and Assessment Office. Cincinnati, OH: US Environment Protection Agency; October 26, 1987.

61. RALSTON N.V.C., RAYMOND L.J. Dietary selenium's protective effects against methylmercury toxicity. Toxicology. 278, 112, 2010.

62. FALANDYSZ J. Selenium in edible mushrooms. J. Environ. Sci. Heal. C. 26, 256, 2008.

63. JECFA. Evaluation of certain food additives and contaminants (Sixty-first report of the Joint FAO/WHO Expert Committee on Food Additives). WHO food additives series, No 58, World Health Organization, Geneva, 2007.

64. BARGAGLI R., BALDI F. Mercury and methyl mercury in higher fungi and their relation with substrata in a cinnabar mining area. Chemosphere 13, 1059, 1984.

65. WHO. World Health Organization, Safety evaluation of certain food additives and contaminants. Food Additive Series No. 52. Joint FAO/WHO Expert Committee on Food Additives, Geneva, Switzerland, 2003.

66. WHO. Evaluation of certain food additives and contaminants. Seventy-third report of the Joint FAO/WHO Expert Committee on Food Additives, WHO Technical Report Series 960, 2011.

67. EFSA. Cadmium in food. Resource document. European Food Safety Authority, 2009. Accessed 10 May 2015.

68. http://www.efsa.europa.eu/cs/BlobServer/ Scientific_Opinion/contam_op_ej980_cadmium_en_ rev.1.pdf?ssbinary=true/.

69. EC. Commission Regulation (EC) No. 629/2008 of 2 July 2008 amending Regulation (EC) No. 1881/2006 setting maximum levels for certain contaminants in foodstuffs. Official Journal of the European Union L 173, 6, 2008.

70. WHO. World Health Organization. Evaluation of certain food additives and contaminants, $41^{\text {st }}$ Report of the Joint FAO/WHO Expert Committee on Food Additives. Technical Report Series No. 837, Geneva, Switzerland, 1993. 